\title{
"Re-establishing the True Worship of God": Divinity and Religious Violence in France after the Edict of Nantes ${ }^{1}$
}

\section{BRIAN \\ SANDBERG}

Malgré que l'édit de Nantes de 1598 soit couramment considéré comme un édit de tolérance ayant mis un terme aux guerres de religions en France, de puissants discours sur Dieu ont continué de susciter des conflits entre calvinistes et catholiques. Ces interprétations ont inspiré les laïques français, et en particulier les guerriers nobles du sud de la France, à s'engager dans des violences religieuses. Cet article montre comment la tâche de "rétablir le véritable culte de Dieu » est devenu l'objectif vital de ces catholiques laïques dans les derniers moments des guerres de religions françaises. La force croissante du mouvement de Contre-réforme dans les milieux nobles catholiques du sud de la France, a finalement provoqué des campagnes violentes dans le but de restaurer le catholicisme par la force; ce qui a rendu toute forme de réelle coexistence religieuse impossible en ce début du XVII siècle.

n 8 August 1599, the bishop of Saintes celebrated mass in the church of Saint-Barthélemy in La Rochelle, restoring Catholic religious practice to the predominantly Protestant city for the first time in three decades. ${ }^{2}$ The significance of restoring the mass to La Rochelle, one of the great bastions of Calvinism within France, was lost on no one. François de Sales responded to the restoration of Catholic practice there by exclaiming: "Would to God that [Catholic] worship could be made as free in Geneva as it is in La Rochelle.”3 A contemporary pamphlet announced that:

God has so touched the heart of His Majesty, that his principal goal is that during his reign God will be served and adored, and his holy church revered. To these ends, after having given to his subjects the singular good of peace, he has also by the same means procured the re-establishment of the divine service in all of the places where, because of the malice of these times, it has been prohibited until now. ${ }^{4}$

Renaissance and Reformation / Renaissance et Réforme, XXIX, 2-3 (2005) /139 
The re-establishment of the mass throughout France had become a vital goal for Catholics in the latter stages of the French Wars of Religion from the 1590 s to the 1620s. The language in this pamphlet constructs a dual agency, simultaneously highlighting God's inspiration for Henri IV and the king's own efforts to ensure that God's church is "revered" in France. Catholics and their God would work together for the "re-establishment of the divine service."

The place of God in society and the nature of the relationship between humans and the divine represented crucial issues during the entire period of the French Wars of Religion, which spanned from 1562 to $1629 .{ }^{5}$ My research suggests that participants in the French Wars of Religion continued to see God's hand at work on earth well into the seventeenth century as Catholics continued to struggle to control contested religious sites. ${ }^{6}$ A number of conferences surrounding the $400^{\text {th }}$ anniversary of the Edict of Nantes of 1598 have effectively called into question the edict's status as a document establishing toleration. ${ }^{7}$ Other recent studies have begun to consider the precedents for the edict, its implementation, its institutions, and its legacy. ${ }^{8}$ Yet, scholars have not yet fully examined the problematic status of God in the very unstable but dynamic early seventeenth-century French society. Catholic conceptions of God and their attitudes toward violence strongly influenced conflict in the religiously divided provinces of Guyenne and Languedoc after the Edict of Nantes, at a moment when the Counter-Reformation movement played a particular role in shaping religious conflict and French society.

Powerful interpretations of God fueled confessional conflict between Calvinists and Catholics after the Edict of Nantes by inspiring French lay people, and especially the warrior nobles of southern France, to engage in religious violence. Lay participants in civil conflicts applied theologies and ideologies of the divine, seeing God as a motivator, or even an agent, of violence during the religious wars. Susan Karant-Nunn, Edward Muir, Barbara Diefendorf, and other historians have pointed out the importance of lay piety and devotional practices in the unfolding of the Protestant and Catholic reformation movements. ${ }^{9}$ God's relationship with humans was clearly in flux in the period of the reformations, and renewed lay participation in religious activity characterized each of the emerging confessions. ${ }^{10}$ In an important work on religious violence during the Protestant Reformation, Lee Palmer Wandel has rightly called for an avoidance of sharp distinctions between the religion of "learned elites" and "popular" religion, suggesting that historians explore a wide range of sources to expose how "theology was expressed in the cultural practices of Christianity." Wandel's study of one form of religious violence-iconoclasm—seeks to demonstrate that for early modern Christians, 
"where and how one worshiped God-both liturgy and ethics-were the expression, the outward form, of one's theology, one's understanding of God and His relation to humankind." 11 I would like to use a similar approach to reconsider the position of God in Counter-Reformation France, particularly as seen by the lay persons most directly involved in religious violence. ${ }^{12}$

This article will address precisely the problem of "re-establishing the true worship of God" during the final stages of the French Wars of Religion, questioning how God's position in the religious beliefs and practices of French Catholics affected both the dynamics of ongoing conflicts and the possibilities of reconciliation. ${ }^{13} \mathrm{~A}$ compelling providentialist understanding of God inspired lay Catholics to participate in Counter-Reformation projects to restore Catholic worship in areas under Calvinist control, and especially those established as places de sûreté by the Edict of Nantes. New Post-Tridentine Catholic devotional practices shaped the ways in which French Catholics viewed the relationships between God and human community. Such views of God motivated Catholic warrior nobles, in particular, to engage in what they regarded as divinely-sanctioned violence to purify communities and fully re-establish Catholicism. The growing strength of the Counter-Reformation movement among southern French nobles ultimately inspired violent campaigns to restore Catholicism by force, making any long-term, meaningful coexistence between Calvinists and Catholics impossible.

\section{The Edict of Nantes and the Counter-Reformation in France}

While many Catholics were initially worried about the promulgation of the 1598 Edict of Nantes, they came to welcome the provisions for the reestablishment of Catholic religious practice and the restitution of ecclesiastical properties throughout the kingdom. The edict's Article 3 forcefully proclaimed:

We command that the Roman, Catholic, and Apostolic religion shall be reinstated and reestablished in all places and parts of this our kingdom and the lands under our obedience where its exercise has been interrupted, that it may be peaceably and freely exercised without any disturbance or impediment. Expressly forbidding every person of whatever estate, quality, or condition they may be, under the above-mentioned penalties, from troubling, disturbing, or molesting ecclesiastics in the celebration of divine service, in the enjoyment and collection of the tithes, fruits, and revenues of their benefices, and all other rights and duties belonging to them; and that all those who have taken possession of churches, houses, goods, and revenues belonging to the said ecclesiastics during the troubles, and who still hold and occupy them, place the ecclesiastics back in full possession and quiet enjoyment thereof, with such rights, liberties, and security as they had before they were dispossessed. Also expressly forbidding those of the said so-called 
Reformed religion from preaching or otherwise exercising that religion in the churches, houses, and habitations of the said ecclesiastics. ${ }^{14}$

Henri IV's instructions to the commissaires sent to implement the Edict of Nantes in Dauphiné explained the details of article 3, specifying that "the principal goal that the king intended by the said édit de Nantes was to reestablish the exercise of the Catholic, Apostolic, and Roman religion in the places where it has been prohibited." 15 These instructions leave little doubt that the edict represented a powerful document for Catholics eager to work at restoring the "true" faith. Counter-Reformation Catholics repeatedly cited such provisions in their negotiations, their demands for access to Calvinistdominated communities, and their calls for the restitution of religious sites under Huguenot control. When Catholics regained access to the Huguenot bastion of Montauban in 1607, the documents granting them permission to practise their faith within the city walls and to reoccupy the church SaintJacques directly cited articles 3 and 20 of the Edict of Nantes. ${ }^{16}$

The Edict of Nantes was an incredibly complex "document," actually consisting of a general edict, a number of particular articles, and two brevets. These elements essentially constituted a compromise peace settlement among a number of political-religious groups within France. ${ }^{17}$ France's parlements delayed registering the Edict of Nantes for months, and many of the courts made critical commentaries. The parlement de Paris finally registered the edict in February 1599, and the parlement d'Aix-en-Provence only fully implemented it in October $1600 .{ }^{18}$ The Edict of Nantes was also buttressed by separate legal rulings dealing with specific issues or specially designated regions. The 1599 Edict of Fontainebleau enunciated special protections for the Catholics of Béarn, for example. ${ }^{19}$ Collectively, these legal instruments constituted a complicated religious peace, which gave guarantees to all of the major participants in religious warfare.

The composite nature of the Edict of Nantes has often been ignored, allowing it to be seen primarily as a document establishing religious toleration for Huguenots. There were historical reasons for the interpretation of the Edict of Nantes as an edict of toleration benefiting Huguenots and presenting Henri IV as a "king of peace." 20 Early seventeenth-century Huguenots certainly attempted to use the edict to protect Calvinist practice, periodically sending cahiers des plaintes to the king. ${ }^{21}$ Like previous religious peace agreements in France, the edict confirmed certain Protestant-controlled towns as places de sûreté, especially in the Huguenot "crescent” stretching from La Rochelle across Guyenne and Languedoc to Dauphiné. The Edict of Nantes also brought with it judicial innovations, creating several chambres de l'édit 
in various provinces with substantial Huguenot populations, allowing them certain legal protections. ${ }^{22}$ But the guarantees that Protestants received were all hesitant and potentially transitory, dependent on a continuing re-authorization by the king. Far from establishing toleration, the edict was intended to halt civil warfare within the kingdom and to provide conditions for the restoration of the Catholic church.

Numerous practical problems undermined the implementation of this sweeping program of pacification and re-establishment of Catholicism, however. As Katherine J. Lualdi argues, the application of the Edict of Nantes "required the cooperation and participation of people from across the social spectrum-royal commissioners, bishops and priests, village consuls and parishioners - who viewed the edict through the lens of their own concerns and preoccupations." 23 The demobilization process did not disarm combatants, and many nobles and communities continued to stockpile arms in their châteaux and fortifications. Huguenots maintained their control over many churches, ex-convents, and appropriated ecclesiastical lands, especially in southern France. Protestants dominated numerous villages and urban centres in the provinces of Guyenne, Languedoc, and Dauphiné. Holding municipal offices and commanding fortifications allowed Huguenots to control access to predominantly Protestant city centres and to limit religious practice within those urban spaces. Despite the work of commissioners, sovereign courts, and provincial governors, Huguenots often were able to delay or prevent the re-establishment of Catholic practice in Protestant-dominated communities and areas. Such delays frustrated Catholics, who felt that the Edict of Nantes was not being fully applied. ${ }^{24}$

Devout Catholic nobles used the Edict of Nantes to advance the goals of the Counter-Reformation movement and to suppress Protestant initiatives in southern France. Anne de Lévis duc de Ventadour applied provisions of the edict to clamp down on Huguenot assemblies in the province of Languedoc. ${ }^{25}$ Counter-Reformation Catholics, who refused to negotiate divinity with Calvinists, worked to restore Gallicanism and identify the king with Jesus's sacrifice and God's fight against heresy. ${ }^{26}$ Royal Gallicanism, a political ideology advocating a clear religious role for the French monarch as well as certain jurisdictional "liberties," represented an important aspect of the French Catholic revival that promoted the supression of heresy. ${ }^{27}$ Catholic nobles and municipal officials aided clergy in taking control of churches and ecclesiastical properties. Many bishops-including the bishops of Montauban, Montpellier, Béziers, and Nîmes - were refugees from their ecclesiastical seats in 1598, since Huguenots dominated the cities and towns where their cathedrals were located. Marc Venard has shown that after 
1598 bishops increasingly used episcopal visitations to assess the damage to churches in their diocese and to begin the process of restoring the mass to their parishes. ${ }^{28}$ Bishops often focused on implementing the edict in urban contexts, and Élisabeth Rabut has noted that in Dauphiné, “concord was no longer defined according to the Erasmian theory of unanimity but in terms of the rules of life in the city, of the virtue of the citizen."29 Bishops in the dioceses of southern France thus were very active in responding to the opportunities presented by the Edict of Nantes, but only with the crucial assistance of devout lay people.

The religious settlement of the Edict of Nantes, rather than ending religious violence or establishing toleration, actually shifted the grounds of conflict. ${ }^{30}$ From the perspective of devout Catholics, the edict opened a new path for the advancement of God's church. When Louis XIII appealed to the staunchly Catholic city of Toulouse for assistance in 1621, his messenger insisted on the importance of re-establishing the church: "the king-moved by the clamors of his afflicted peoples, by the sighs of the oppressed church, and by the moving voice of the religion of his fathers-is rushing for the second time from the other end of his kingdom to this one...risking his life to rescue you from your calamities." 31 The Edict of Nantes sanctioned the goals of the Counter-Reformation movement and made the restoration of the "true" faith a vital imperative for devout Catholics.

\section{Perceptions of God in the Counter-Reformation}

The Counter-Reformation movement that aimed to re-establish God's church in France following the Edict of Nantes represented an outgrowth of Catholic renewal currents stretching back more than a century. ${ }^{32}$ Various revival and devotional movements had sprung up from the "violent disruption" of late medieval religiosity, as Eamon Duffy has referred to the early reformation. ${ }^{33}$ Within France, a new multi-faceted Catholic Reformation was underway even as Calvinism began to spread in the kingdom in the 1530s. ${ }^{34}$ Christian unity had gradually fragmented throughout Europe, then collapsed within France in the wake of the death of Henri II in 1559 as religious violence broke out. Outraged Catholics had responded to Huguenots' mockery of the mass, iconoclastic attacks, and destruction of communion wafers during the early religious wars of the 1560 s. ${ }^{35}$ Intense penitential movements had formed in the 1570s and 1580s, as new holy confraternities and Catholic Leagues organized. ${ }^{36}$ Meanwhile, the decisions of the Council of Trent had presented a more coherent and systematized form of Catholicism, which were supported by reinvigorated Catholic institutions. However, the chaos and disruption of 
religious warfare during the 1580s had prevented French bishops and other Catholic leaders from fully implementing this approach to Catholic reform. The Counter-Reformation movement that aimed at restoring Catholicism had begun to spread into France by the 1590s, and it gathered strength with the issuing of the Edict of Nantes. ${ }^{37}$

The dévots-as devout Catholics in early seventeenth-century France were sometimes called-thus did not constitute a political "party," but instead can be seen as active participants in a profound religious renewal movement involving French Catholics from diverse social backgrounds. The dévots placed great importance on being bon Catholique, a phrase often misunderstood in modern historical literature. Too great a distinction is often drawn between the concepts of bon Catholique and bon Français, which are often defined as sharply divergent polemical positions based on a narrow reading of contemporary pamphlets. ${ }^{38}$ For early seventeenth-century French Catholics, being bon Catholique meant displaying one's love of God through daily devotional practices and fervent proclamations of belief.

The principal sources for exploring these bon Catholiques' conceptions of God and their attitudes toward the divine in early seventeenth-century France are manuscript correspondence and reports. The proceedings of diocesan and provincial assemblies reveal how social elites considered God's role in the troubled decades following the Edict of Nantes. Wills, contracts, and other familial documents offer additional information. Relatively few livres de raison have been unearthed for this period, although I have consulted some. ${ }^{39}$ These manuscript sources can be contextualized through a comparison with contemporary printed pamphlets, treatises, and memoirs dealing with religious politics and devotional activities. Early seventeenthcentury French religious art portrays Catholic dévot religiosity in diverse contexts. Depictions of the divine can be discerned in paintings, drawings, and engravings narrating Jesus's life and miracles, enacting the crucifixion and resurrection, celebrating Marian theology, and illustrating saints' lives. ${ }^{40}$ Despite the fragmented and limited nature of the available evidence on Counter-Reformation religious motivations and ideologies, these varied sources do reveal traces of the complex textual and visual images of God used by early seventeenth-century French Catholics in their religious expressions and practices.

Following the dissolution of the Catholic Leagues, Catholic divine images presented God as giver of divine love, protector of the faithful, guardian shepard, and merciful father. ${ }^{41}$ A painting of Le concert des anges, ou le Père éternel entouré d'anges, attributed to Philippe de Champaigne and possibly commissioned by Marie de Médicis portrays a radiant benevolent divine 
father presiding over a tranquil concert of angels. ${ }^{42}$ Early seventeenth-century Catholic writers also employ such imagery, but simultaneously represent God as a majestic and powerful sovereign, whose status must be glorified and whose commands must be obeyed. Pierre Bérulle in particular stresses the analogy of God as the almighty king of kings. ${ }^{43}$ When disobeyed, God could be full of wrath, wreaking vengeance against the unfaithful. Jacques Callot's and Nicolas Poussin's terrifying visions of destruction, massacre, and martyrdom can be seen as Post-Tridentine representations of God's retribution and vengeance on a sinful world. 44

Devout French Catholics repeatedly described feeling God's presence as a close, personal relationship. French believers could draw on Catholic devotional literature by such devotional guides as Teresa de Ávila, Ignatius de Loyola, and François de Sales-who portrayed God's love in terms of friendship. ${ }^{45}$ Devotional paintings by Georges de La Tour, Simon Vouet, Jacques Callot, and the Le Nain brothers often presented religious experience as intimate, interior, and contemplative through the popular images of Mary Magdalene, Jerome, and Francis of Assisi. ${ }^{46}$ Counter-Reformation Catholics envisoned God's public presence above all through the communion mass and the sacrifice of the Eucharist. ${ }^{47}$ Counter-Reformation Catholics felt it a holy duty to defend the Eucharist as the body of Christ and to uphold the sanctity of the mass. The early seventeenth-century polemical writings of Jesuit François Veron vigorously defended the Eucharist from Huguenot attacks. ${ }^{48}$ French Catholics' responses to iconoclastic attacks by Huguenots may have forged new appreciations of the location and visual representation of God. ${ }^{49}$ French Catholics claimed to sense God's presence through devotional and ritual activities that emphasized the seen, felt, and even tasted divine.

Montpellier Catholic André Delort provides a fascinating glimpse into the attitudes of southern French Catholics to the mass in the early seventeenth century. Montpellier was a religiously mixed city during the religious wars, with a population of approximately 15,500.50 When Huguenots took control of the city during the 1621 civil war, they outlawed Catholic practice, prompting many of the Catholic residents to flee as refugees. A few Catholics remained, attending secret religious rituals held in cellars by priests who disguised themselves and "dared to celebrate the holy sacrifice of the mass."51 Delort believed that this subterranean preservation of the mass at Montpellier showed the falseness of a period Calvinist polemical piece, the Tombeau de la Messe. ${ }^{52}$ This Montpellier dévot confidently declared that "the true Church may well be agitated but not submerged by the wave of heresies." 53 The Protestant-controlled city endured a siege by a Catholic army in 1622, during which Huguenots committed many "disorders" and "insolences" within the 
walls. Delort felt vindicated when, after a peace agreement ended the siege, Louis XIII entered Montpellier and "established the true religion."54

The "true religion" was re-established, for Delort and his co-religionaries, when practice of the mass was in the open and unrestricted. CounterReformation Catholics regarded the public display of God as crucial, especially through civic religious processions, such as Eucharist processions of the Blessed Sacrament. ${ }^{55}$ The dimensions of Catholic ceremonial processions can be seen in celebrations of a jubilee at Fontainebleau and Paris in 1620. Louis XIII and his court went to Fontainebleau for the jubilee along with eight to ten Jesuits, who were to hear confessions. In Paris, a series of processions were held with "great solemnity." A "multitude of people" participated in these processions, according to one observer, who claimed that the processions became so large that it was "very difficult to enter the churches." The princes and princesses were going "on foot to do the stations [of the cross]," and display their devotion. ${ }^{56}$ Similar religious enthusiasm and devotion could be seen in processions in Montpellier and Toulouse in the 1620s. The emplacement of crosses in squares and prominent civic spaces in Catholic-dominated cities in this period confirmed the Catholicity and devout nature of communities. ${ }^{57}$

Such public displays of mass religiosity demonstrated the zealousness of the Catholic faithful and attracted many new converts in this period. ${ }^{58}$ Early seventeenth-century French Catholics were increasingly confident about the spread of the apostolic faith, but they also recognized the danger of fresh conversions to Protestantism, such as the much-publicized conversion of the duc d'Épernon's son to Calvinism in $1616 .{ }^{59}$ Catholic parishoners also worried about the possibility that insincere conversions to Catholicism might allow Huguenots to pollute the mass. Nonetheless, conversions of Protestant nobles and clergy to Catholicism were considered important events, and Catholic pamphleteers publicized them widely, especially when such prominent grands as François de Bonne duc de Lesdiguières converted. ${ }^{60}$

Counter-Reformation Catholics considered God as the giver of good government, providing a certain degree of order to an imperfect and sinful world by annointing just rulers and protecting "true" Christians from tyrants. Contemporary theories of monarchy, often problematically labeled as "divine right" theories, inserted monarchs into a divinely ordered hierarchy of obligation to God. ${ }^{61}$ According to this view, the Creator had crafted natural laws and had authored principles of good government. Ceremonies established the religious basis of monarchical government, most explicitly in the curing ritual of the king's touch and the theory of the king's two bodies. ${ }^{62}$ Rubens's 
famous painting cycle for Marie de Médicis drew on these notions of the divine origin of good government in imagining her regency government. ${ }^{63}$

The same notions of divinely-conceived rule also shaped Catholic attitudes toward regional and local government. In Catholic-dominated northern France, the Catholic Reformation steadily gained strength in the late sixteenth and early seventeenth centuries, but Paris had long been a centre of Catholic renewals and had been referred to as the "New Jerusalem" at the time of the Catholic League. ${ }^{64}$ Major Catholic "bastions" such as Bordeaux and Toulouse provided bases for the installation of Catholic reform in Southern France. 65 As the Counter-Reformation movement spread through France, Catholics increasingly focused on civic leadership and pressed for control of municipal government through the consulats. François Estrades wrote enthusiastically from southern France: "thank God, we have elected in this place consuls [who are] staunch Catholics, great servants of the king, persons who have much to lose and [who are] most agreable to the good people." 66 Catholics believed that local magistrates and judges should fufill important roles in the divine order of the world. Henri I de Montmorency duc de Montmorency explained in 1613 the need for judicial enforcement of order in his province of Languedoc: "it is greatly important to the state to demonstrate that justice is still strong and powerful in correcting and punishing those who trouble the public peace." Montmorency worried about "the connivance which previously engendered revolts and seditions so frequently in the Huguenots towns of this province...there is only one single way to repress them, it is the power of justice.” Montmorency clearly associated Protestants with rebellion, and thus with heresy, implying that the magistrates should aggressively correct the errors of the Huguenots. The judges in Languedoc, he believed, should "join prudence and circumspection to their zeal, assuring themselves that God will favor their work." 67

The ways in which Counter-Reformation French Catholics imagined God thus inspired them to undertake various public ritual displays of the divine. In religiously-mixed southern France, Catholics constantly experienced troubling division and disorder, confronting "heretics" in their daily lives. Catholics and Calvinists often resided in close proximity, and some of them even cohabited in mixed-confession communities. Catholic worship and devotional activities in the south reflected both lay Catholics' fears of heretical pollution and their desires for religious unity. ${ }^{68}$ Robert Sauzet reveals the experience of Catholics living in the midst of the Huguenot "crescent," focusing especially on the case of the notary Balthazar Émenard. ${ }^{69}$ Catholics throughout Languedoc and Guyenne, the provinces with the largest concentrations of Protestants, saw God as providing strength to endure the ordeals 
of life when threatened by heresy. For devout Catholics, then, expressions of unity were demonstrations of a merciful God, who must be trusted fully and completely.

\section{Submission to God's Will}

Restoring the church in war-torn France required the submission of all "true" believers to God's will. Late sixteenth- and early seventeenth-century French Catholics believed that relating to God involved fully accepting divine direction. Conforming to the will of God emerged as a central concern of early seventeenth-century Catholic devotional writers, such as Benoît de Canfield and François de Sales. ${ }^{70}$ Fervent Catholics’ spirituality was shaped by an emotional release experienced through what they saw as complete obedience to divine guidance. Barbara Diefendorf argues that for devout Catholics, "the aim of all good spiritual direction was not to create dependence on another but to tame-ideally, to destroy-the penitent's self-will, so as to leave her [or him] dependent on, and totally submissive to, the will of God."71

The act of surrendering oneself to God transpired through personal devotion and lay religiosity. French Catholics engaged in hours of prayer, often conducted while secluded in private chapels. Private devotions employed simple implements such as crucifixes, prayer beads, images of saints, and books of hours to facilitate contemplation of God. Catholics cultivated an interior spirituality that sometimes included trances, visions, and other forms of mysticism. Spiritual guidance was available through Ignatio Loyola's Spiritual Exercises, François de Sales's Introduction à la vie dévote, and other spiritual writings. Devout Catholics absorbed themselves in singing during their personal devotions and domestic religiosity. ${ }^{72}$

French Catholics embraced God through various forms of asceticism in the early seventeenth century. Many adherents performed devotions through temporary ascetic experiences, such as hermitical retreats, pilgrimages, and solitarity contemplation. Others entered mendicant religious orders or dedicated themselves to monastic life, a particularly attractive form of asceticism for devout Catholic women. ${ }^{73}$ The Lorraine family women promoted an ascetic devotional model in this period through their direction of convents and participation in cloistered life. ${ }^{74}$ French men and women enthusiastically joined the Feuillants, Capuchins, Jesuits, Ursulines, Visitandines, and other religious orders dedicated to restoring Catholicism throughout France. New monasteries and convents were founded, with 48 new women's convents being founded between 1604 and 1650 in Paris alone. ${ }^{75}$ 
Catholics also sought closeness to God through outward devotional acts, often intended to fulfill vows made to God in the context of prayer. Lay religiosity involved daily participation in collective rituals and religious activities outside of the context of the mass. French Catholics gathered in chapels, homes, and streets to pray, sing, and listen to preaching. Popular public devotional practices in this period included the Forty Hours celebrations, "which included continual display of the Eucharist, preaching, confraternity processions, theater, and music."76 Lay Catholics participated in an intense revival of Marian devotion at shrines and chapels across France. ${ }^{77}$ The Catholic faithful in religiously-mixed southern France cultivated their relationship to God through all of these collective activities.

Marie de Médicis' own devotional activities demonstrate how devout Catholics could combine various aspects of religiosity in their personal piety. Marie went on a number of pilgrimages to Nôtre Dame de Liesse. ${ }^{78}$ Marie provided financial patronage and political backing for the Feuillants' order and their work in France. ${ }^{79}$ Following Henri IV's reinstatement of the Jesuits within France in 1603, Marie assisted in the expansion of the Society of Jesus in the kingdom, selecting Jesuit Jean Suffren as her confessor in $1615 .{ }^{80}$ The queen mother actively supported the publication of religious texts, including a new Bible printed in Paris. ${ }^{81}$ Marie de Médicis’ well-publicized devotional activities and religious patronage provided examples for devout Catholics throughout France.

A dévot's submission to God was signified through pain and self-mortification. Bodily suffering and flagellation played important roles in Catholic lay piety in the late sixteenth and early seventeenth centuries. ${ }^{82}$ Brad S. Gregory demonstrates Post-Tridentine Catholics' "impulse to imitate Chirst through the patient suffering of adversity." ${ }^{33}$ Henri III had set a moving royal example of piety and suffering in collective penitence ceremonies during the 1580s. Catholic Leaguers had adopted many of these same devotional practices, despite their growing suspicions that their "blasphemous" king was promoting penitence as a duplicitous show. ${ }^{84}$ Leaguers had doubted the sincerity of Henri de Navarre's conversion to Catholicism in 1593 in part because they felt that he had failed to perform appropriate penitential acts. ${ }^{85}$ The dévots of the early seventeenth century focused on a more personal approach to penance and suffering that was "intended to destroy self-will so as to allow the mortified subject to be infused with the will of God," according to Barbara B. Diefendorf. Many dévots employed hair-shirts, whips, and thorns in ritualistic self-mortification. "Ascetic self-discipline,” Diefendorf argues, "produced individuals who were humble and yet confident in their intimate knowledge of the will of God." 86 
Devout Catholics resigned themselves to the possibility of meeting violent death as they risked their lives in the service of God. Submission to divine will demonstrated Catholics' determination and resolve in their efforts to restore the church, even if they faced martyrdom. Brad S. Gregory defines a Counter-Reformation "ethos of martyrdom" that inspired Catholics to resist "heretical seduction" and to suffer persecution, interrogation, torture, and death. Catholic writers of martyrologies and hagiographical collections glorified and exalted martrydom, portraying Christ as "the king of martyrs." Lay Catholics, he suggests, viewed martyrdom as "the highest form of the imitation of Christ." 87 Gregory's analysis of Catholic martyrdom overly concentrates on English Henrician and Dutch Catholic martyrs, failing to appreciate the broader dimensions of Catholic martyrdom in the European religious wars. ${ }^{88}$ Allan A. Tulchin reminds us that French Calvinists massacred hundreds of Catholics in Nîmes and La Rochelle in the 1560s when the conditions were ripe for mass murder. ${ }^{89}$ Historians often seriously underestimate the magnitude of Catholic martyrdom during the European religious wars by considering only the victims of judicial violence and massacre. Lay Catholics, priests, and missionaries killed in religious conflict and siege warfare during the French Wars of Religion were often celebrated as martyrs by their contemporaries, both through direct references and through religious art, such as paintings of massacres and martyrdom by Nicolas Poussin. ${ }^{90}$

The beliefs and practices of Counter-Reformation Catholicism reinforced French Catholics' determination to oppose Calvinist heresy and to demonstrate their obedience to God. Episcopal leadership in French dioceses and clerical debate in a series of Assemblies of the Clergy stressed the importance of Catholic believers' submission to God. ${ }^{91}$ Many southern French Catholic nobles and civic elites were swept up in the religious renewal of the Counter-Reformation movement, believing that they were performing their divinely-ordained duty. Members of the parlement de Toulouse, for example, saw submission to the divine will as being a prerequisite for service to God. In a letter to the duc de Montmorency, the parlementaires argued that: "Our interests consist only in the service of God, the maintenance of the king's authority, the peace of his subjects, the execution of his sovereign justice."92 Living in a region filled with so many "heretics" required Toulousains to demonstrate patience by submitting to the will of God and waiting for divine action to restore the true church. 
152/ Renaissance and Reformation / Renaissance et Réforme

\section{The Hand of God}

Devout French Catholics prayed daily for God's direct intervention in human affairs, believing that God clearly worked miracles among humans on earth. Thunderstorms, floods, fires, and other natural disasters produced simultaneous evidence of God's anger and his mercy. The unexpected survival of people and belongings in the midst of catastrophe represented miraculous intervention by God and his saints. While Protestant criticisms of the working of miracles forced Catholic clergy to elaborate and reformulate their theories of the miraculous, lay Catholics continued to believe in miraculous events and phenomena. Whatever hesitations Protestants may have had about healing miracles, French Catholics saw God playing a direct role in human illness, injury, and death. ${ }^{93}$ Mark Greengrass, who has studied miracle-stories in sixteenth-century pamphlets, finds that "the major concern," for Catholic writers, "was to combat Protestant pamphleteers....With the miracle-story, and the performativity and participation that were its essential components, Catholic pamphleteers claimed a proof that God intervened directly in natural and human affairs, and in support of the traditional religion."94 Divine providence explained why a young Bordeaux woman who was "impious and ungrateful" was "chastized and punished by the hand of God," according to an early seventeenth-century chronicle. ${ }^{95}$ At times, French Catholics' writings reveal their expectancy, as they anxiously awaited evidence of God's hand. A memoir's account of the siege of Montpellier in 1622 commented on God's inscrutability in death: "We must believe that the hour has not yet arrived, and [we must] admire the secrets of God who permits so many considerable [noble] men to die so miserably." 96

Counter-Reformation notions of providence emphasized miraculous interventions in everyday, human life, assuming that humans especially needed God's miraculous intervention in desperate situations. Studies of contemporary Spanish Catholic sailors suggest that storms provoked moments of "intense devotion" and repentence. ${ }^{97}$ French Catholics embroiled in religious warfare often experienced crises and life-threatening situations that may have produced similar intense religiosity. During civil conflict in southwestern France in 1616, a Catholic noble despaired of halting oncoming Protestant forces, despite the "affection" that he and other Catholic nobles had for the king's service. Their efforts were "useless," he claimed, and "there is only God who can do something."98

Devout Catholics relied on saintly intercession to guide God's hand in working miracles. Brad S. Gregory demonstrates that "Catholic trust in divine providence included belief in the saints' intercessory powers." 
Saintly intercession could provide miraculous protection and salvation, and Gregory specifically cites the healing miracles attributed to "new martyrsaints" throughout Europe. ${ }^{99}$ Appeals to newly martyred Catholics joined with invocations of well-established saints and Marian devotional practices. The epidemic disease that raged in southern France in the wake of the 1629 civil war was considered to be sent by God. In response to the plague, Montpellier Catholics "offered and consecrated to God" paintings of the Virgin Mary and Christ child. ${ }^{100}$ French Catholics who were involved in religious warfare regularly invoked saints' assistance in speeding divine intervention.

God did not always act in dramatic fashion or in immediately visible ways, however. God was also believed to provide guidance and inspiration for humans to act. For French Catholics, this providentialism was discussed as the guidance of the Holy Spirit, and could be seen especially through the actions of the king. When Louis XIII decided to head to Angers during the 1620 civil war despite varying counsel, it was "God who inspired the king," according to some Catholic observers. ${ }^{101}$ The king himself recognized God's aid when the town of Saint-Jean d'Angély capitulated in 1621, exclaiming that, "finally rebellion has ceded to the force of my arms, and God has demonstrated his judgments and how he is assisting me."102

God stirred humans to advance the work of rebuilding the church, inspiring benevolent works and charity among the Catholic faithful. Catholics in southern France described the foundations of new monasteries as the work of God accomplished by humans. Jean de Gaufreteau recorded the founding of the Ursuline convent in Bordeaux, indicating that "God has so blessed [the founder's] intention that from a small beginning, as one can say, he has caused a fly to give birth to an elephant. For it is today considered the richest convent in Bordeaux." 103 The new Counter-Reformation religious orders increasingly established missions in southern France, working to sustain devout Catholics and to convert stubborn "heretics."

Despite their growing confidence, Catholic missionaries and lay people alike seem to have regarded conversions as miracles worked by God to protect communities from the influence of Satan. Ignorance could bring "a diversion by Satan, to his profit, of the devotional practices due to God alone," Catholics believed. ${ }^{104}$ An episode of mass conversion in the town of Aubenas suggests the possible dimensions of human involvement in the re-establishment of the church. A contemporary pamphlet dedicated to the king claimed that Aubenas' Catholics, "having made a thousand vows for the success of your royal arms, have harvested in their own homes and within their walls part of the fruit that they did not dare to desire....the sudden and 
marvelous conversion of their fellow citizens, who had professed the contrary religion-absoutely work of the hand of God."105

While the restoration of the faith thus seemed to be on course, God's plan was ultimately unknowable. The long siege of the Protestant city of Montauban in 1621 shook the confidence of some Catholic soldiers, who endured bombardments, assaults, famine, and disease for months in the trenches before the Catholic army finally abandoned its siege. Mark Juergensmeyer's sociological research suggests that combattants in religious warfare often confront the problem of knowing the "mind of God." ${ }^{06}$ During the CounterReformation, human difficulties in understanding the natural world and the creator were held to stem from the Original Sin. While René Descartes thought that humans could discern the image of God in their minds, many sixteenth- and seventeenth-century people believed that humans were unable to grasp the image of God. ${ }^{107}$ French Catholics could never fully comprehend the divine plan, but they believed that God gave them signs and suggestions of his will.

Astronomical phenomena and seemingly abnormal portents provided humans with signs of God's will. ${ }^{108}$ Hailstorms, strange cloud patterns, and lightening strikes offered clues for the faithful to read portions of the inscrutable divine plan. Comets, eclipses, and falling stars all signified portents to early seventeenth-century observers. ${ }^{109}$ Deformed humans and animals could represent horrendous monstrosities to Counter-Reformation Catholics. "While the Catholics did not reject all prodigies,” R. Po-chia Hsia suggests, "they were more cautious in accepting monstrosities as signs of God's will, especially after the initial fervor of religious polemic in the 1520s and 1530s in the Empire. After the Council of Trent (1547-62), this caution was even more pronounced." 110 Despite such reticence on the part of ecclesiastical elites, French lay Catholics continued to report monstrous births and deformations as significant events, often with religious implications. ${ }^{111}$ Chroniclers in southern France recorded the arrest of a werewolf in Bordeaux in 1611 and the arrival of conjoined twins in Montpellier in $1625 .{ }^{112}$ CounterReformation mystics and astrologers attempted to interpret portents as guides to proper action by the dévots. ${ }^{113}$

Many Catholics were convinced of God's anger at the presence of heretics in their communities. Changing Catholic views of persecution and toleration throughout the French Wars of Religion were linked to understandings of the divine will. Philip Benedict explains that "Catholic opinion about the practical wisdom of tolerating two faiths oscillated significantly as the Wars of Religion advanced." 114 Barbara Diefendorf has shown that Parisian Catholic priests in the 1560s and 1570s preached that "the spread of heresy 
is a sign of God's anger and a warning of his impending judgment, for does not the bible warn us that 'iniquity and error will abound' and that this will be one of the signs that the last days are upon us?" 115 Catholic nobles who engaged in religious warfare in the early seventeenth century often described God's anger at rebellious heretics. In 1628, the Catholic prince de Condé condemned the "heretic" Huguenot duc de Rohan, claiming that "you bring God's curses and the king's anger on yourself by your disobedience....God compensates you according to your good works and gives you a good correction."116 Apocalyptic visions reminded Catholics that God's intervention inevitably guided the earth toward the Last Days, the arrival of which many Counter-Reformation Catholics assumed was imminent.

\section{God's Battles and the Soldiers of God}

The re-establishment of the church had Apocalyptical significance for Counter-Reformation Catholics, who regarded religious violence as an integral part of God's plan. Interpretations of Christian eschatological texts offered various chronologies and scripts for the predicted events of the Last Days, which included the coming of war, plague, famine, fire, and destruction; the deception of the Antichrist; the arrival of the Whore of Babylon; and the exposing of Satan himself. Prophesies agreed that the end result of the Apocalypse would be a restoration of God's church and the salvation of the faithful, often depicted as a New Jerusalem. ${ }^{117}$

Catholics regarded the Second Coming of Christ as intertwined with heavenly battle. The restoration of the "true" religion would be accomplished through God's battles against Satan. The book of Revelation offered a cataclysmic vision of heavenly battle in the Last Days:

\footnotetext{
And there was war in heaven: Michael and his angels fought against the dragon; and the dragon fought and his angels, And prevailed not; neither was their place found any more in heaven. And the great dragon was cast out, that old serpent, called the Devil, and Satan, which deceiveth the whole world: he was cast out into the earth, and his angels were cast out with him. ${ }^{118}$
}

This vision of heavenly battle represents a "cosmic war" to use Mark Juergensmeyer's terminology. Juergensmeyer, a sociologist who studies religious violence and terrorism comparatively, suggests that "images of divine warfare are persistent features of religious activism. They provide the content and the themes that are played out in the grand scenarios that lie behind contemporary acts of performance violence." ${ }^{119}$ Historian Denis Crouzet, while not drawing on Juergensmeyer's theories, comes to a similar conclu- 
sion concerning the dynamics of violence in the French Wars of Religion. Crouzet, in an extremely complex analysis of polemical pamphlets of the religious wars, finds that the discourses of violence stemmed from a deep eschatological crisis, which created a widespread belief in the immediacy of the Last Judgment and a conviction that "violence is from God." 120 Catholic pamphleteers assumed that "God sometimes uses the common people as the agents of his vengeance,” according to historian Barbara B. Diefendorf.121

The soldiers of God exercised an exceptional sort of agency as direct instruments of violence whose roles distinguished them from the overall devout Catholic community. R. Scott Appleby distinguishes several types of "religious actors," pointing out that only some religious actors can be considered "extremists" - individuals "who employ violence as a privileged means of purifying the community and waging war against threatening outsiders." ${ }^{122}$ Appleby specifies that religious actors are usually subgroups who set themselves apart from other adherents of their religion, although they may claim to act on behalf of the entire religion, and of God. Juergensmeyer likewise sees religious "warriors" as having a special status, strengthened by "symbolic empowerment." 123 Catholic participants in the religious wars, and especially those in the mixed-confessional zone in southern France, believed that select humans would enact God's will in the "cosmic war" of the Last Days. Crouzet argues that Catholic participants in religious violence sacralized violence to such a degree that they represented their bodies as possessed by God when carrying out acts of violence against persons that they considered heretics. ${ }^{124}$ Devout militant Catholics thus exercised a special dual agency with God in committing violence. ${ }^{125}$

Although source limitations prevent a detailed study of the largely illiterate common soldiers, we can get indirect glimpses of ordinary Catholic soldiers' motivations and attitudes during the religious wars. Pierre Émenard, a Catholic notary's son in Languedoc, was mortally wounded in the assault on the Protestant town of Meyrueis in 1628. Balthazar Émenard, Pierre's father, described his son's multiple wounds in detail and specified that Pierre had been buried "following the Catholic form.” While no record of Pierre's own religious thinking remains, his father's views of God offer some appreciation of the religious environment in which Pierre was raised and his possible religious motivations. "In the first place," Balthazar recorded, "I thank you, My God, with all my heart that you in your mercy have dignified me by my birth to Christian and Catholic parents, through whose careful diligence I was reborn in the holy founts of baptism and indoctrinated in the faith of his Catholic Church, which is the unique house of salvation in which one can find the ladder for climbing to heaven."126 Strong religious 
convictions probably motivated many of the commoners who served as soldiers in Catholic armies during the wars of religion. Nobles' descriptions of military operations reveal that ordinary Catholic soldiers went to mass even on campaign, engaged in battlefield prayer, and consulted the priests who accompanied Catholic armies. ${ }^{127}$ Unfortunately, the best study to date of warfare during the French Wars of Religion offers little information on religious motivations, and the best historical model of combat effectiveness considers religion only indirectly. ${ }^{128}$

Contemporary sources allow a more thorough examination of nobles' participation in religious warfare. Counter-Reformation writers often depicted nobles as the principal human actors in God's battles, suggesting that Catholic nobles offered their military service and their lives to God as devotional acts. A pamphlet written to memorialize Henri de Schömberg claimed that "I always saw him with a soul as tranquil as his great health. I saw him offer with joy, at the feet of the cross of Jesus Christ, this life that he employed with so much zeal for the re-establishment of his altars."129 The correspondence of elites in southern France often displayed similar devotional pledges and referred to nobles' participation in religious warfare as divinely inspired. The états de Languedoc recognized Henri II de Montmorency duc de Montmorency as an agent of God in re-establishing true faith in their province, thanking him for "the diligence of your work, the wisdom and faithfulness of your counsels, and the incomparable generosity of your conduct.” The deputies linked Montmorency's efforts with those of Louis XIII. The états proclaimed to the duc that "you have given to this Languedoc the certain proofs of this truth in re-establishing the true worship of God, the king's service, and the peace of the people." 130 French Catholic nobles were important participants in the broad Counter-Reformation movement intended to halt the spread of Protestantism.

Devout Catholic combatants saw themselves as soldiers of God, special lay activists who were marked by their military service to the "true" church. French warrior nobles often enrolled in confraternities and military orders to express fully their activist sentiment of divine service and sacrifice. ${ }^{131}$ Many French Catholic nobles travelled abroad, serving in Habsburg-led armies opposing Ottoman forces along the Hungarian frontier, or in international fleets fighting Ottoman and North African warships in the Mediterranean. ${ }^{132}$ French nobles who wanted to serve in the chevaliers de Malte often depicted their bellicose actions as glorifying God. ${ }^{133}$

For Catholic warrior nobles, taking up arms was a religious act. Mobilizing for warfare allowed Catholic nobles to assemble fellow devout believers in an armed community of lay activism. Louis de Chabans praised 
"the courage, the generosity, and the diligence" of the nobles and soldiers with whom he served, claiming that if they had lost few men in this campaign, one should "truly attribute it to the singular protection that it pleases God to take up the arms of the king, who carries a dreadful fear to his enemies." ${ }^{34}$ Mobilizing for war and recruiting soldiers simultaneously represented religious devotion and royal service. Henri de Schömberg thus raised two hundred infantry in 1619, hoping "with the aid of God that I can render a good service to the king." 135

The nobles who funded and organized religious warfare considered war financing as an expression of religious zeal. Early seventeenth-century Catholic noble officers often clothed, armed, funded, fed, and supplied the military units that they commanded using their personal credit and appropriated funds. Such alternative financing and credit mobilization techniques have often been understood through the lens of "military entrepreneurship," yet Catholic nobles seem to have employed lay associations and religious networks in organizing war finance. ${ }^{136}$ Religious motivations seem to have contributed to Catholic nobles' considerable investment in war finance through individual spending and institutional contributions. The assiettes, or diocesan assemblies, of southern France frequently funded religious warfare in the name of God and the king. During the assiette de Lavaur's deliberations for a new contribution, a royal messenger asked the largely noble deputies to remember "the pains and works that His Majesty took last year for the maintenance and affirmation of his repose and authority of his kingdom and since he does not have... other view but the good of his subjects.” The messenger optimistically suggested that "it has pleased God to bless his design so much that His Majesty has every occasion to hope to re-establish in little time so good an order in all things that he might deduct several expenses... and in this way relieve his people." 137 When the deputies responded with funds, they could envision themseleves as good Catholics acting with God for the common good of restoring the church and subduing rebellion.

The armies assembled and maintained by Catholic warrior nobles waged warfare utilizing overt religious strategies and operations. The campaigns of God's soldiers brought visible results, which could be celebrated publicly in the successive communities in which Catholic practice was restored. A Catholic noble portrayed God as speeding the progress of Catholic armies in Languedoc in 1622: "everyone was astonished to see [Sommières] taken in so little time, admiring in these great exploits the particular assistance of God and the happiness of the king." 138 Many Catholics depicted the king's army as divinely guided during the Béarn campaign of $1620 .{ }^{139}$ Some historians have presented the latter stages of the French Wars of Religion as a series 
of campaigns based on uncomplicated strategy, unnecessary sieges, and attritional warfare. ${ }^{140}$ Such a view misrepresents the goals of the participants in religious warfare and underestimates the significance of control of urban space during the French Wars of Religion. The "soldiers of God" waged campaigns of religious conquest that allowed Catholic clergy and lay people access to religious sites and sacred spaces. ${ }^{141}$

Devout Catholic nobles relied on divine protection and inspiration in fighting what they considered to be God's battles. Modern models of combat motivation have often contemplated how social and cultural factors played a role in the "initial" motivation that enticed officers and soldiers to join armies and in the "sustaining" motivation that convinced them to remain in armies despite the hardships they experienced. However, political and religious causes have often been considered peripheral to human motivations in the midst of actual combat. ${ }^{142}$ Early seventeenth-century Catholic armies seem to have employed combat motivation with distinct religious dimensions, and noble officers appealed to God to sustain their fellow officers and soldiers during combat. Nobles' letters and memoirs offer suggestive evidence that the stirring mission of Counter-Reformation Catholicism inspired officers and soldiers in the midst of combat. During the siege of Montauban in 1621, maréchal de Praslin asked François de Bassompierre to take command of some of the Catholic artillery that had come under fire from the Protestant defenders, saying: "for God, my son, go to the battery."143 Such battlefield invocations of divine purpose present interpretive dilemmas, since they were always recorded later in complex textual sources, yet they invite consideration of the possibility that a strong religious component contributed to Catholic combat motivation in this period. When assaulting cities, Catholic soldiers were intent on attacking heresy and purifying communities by purging pollution. Huguenot temples and homes naturally became targets of destruction and looting during successful siege assaults by Catholic troops.

The Catholic militancy expressed by the "soldiers of God" encompassed complex and diverse responses to the perceived threat of heresy in French society. The Counter-Reformation notion of the Church Militant has sometimes been associated with "fanaticism" and the promotion of a divinely-sanctioned exterminationist policy. Interpretations of the violence of the French Wars of Religion have sometimes portrayed Catholic militancy as genocidal, reminiscent of the modern t-shirt slogan, "Kill them all, let God sort them out.” This slogan refers to the infamous declaration by the papal legate on the Albigensian Crusade to give no mercy to the besieged city of Béziers in 1209, saying "Kill them all, God will know his own."144 Natalie Zemon Davis's seminal article on "rites of violence" reminds us how problematic 
such a view of "fanaticism" in the religious wars can be. ${ }^{145}$ Catholic soldiers and lay people did commit massacres and other atrocities, and contemporary Huguenot pamphlets certainly did focus on accounts of Catholic persecution. The religiosity of the "soldiers of God" was multi-faceted, however, and we must be attentive to the complexity of Catholic militancy. The contradictions in Counter-Reformation notions of God placed certain limitations on Catholic violence and created ambiguities in Catholic militancy. Oddly, one of the most unequivocal calls for extermination in the conflicts after the Edict of Nantes came in 1615, and was focused against rebels who could not all be clearly branded heretics: "great God sounds the trumpet with the command, as of old, to exterminate all these rebels, sparing neither their relatives nor their friends: It is a gentle act to condemn them promptly.” This pamphlet promotes an ambiguous notion of the targets of violence: "yes, French people, it is at this moment that one must take up arms without concern against whom, but only for whom: it is for our king." 146 God's will was not always taken to be so clear, and God was rarely understood to be carrying out a truly annihilationist policy on all heretics and unbelievers.

Despite the ambiguities of Catholic militancy and the infrequency of overt calls for the implementation of exterminationist policies, CounterReformation understandings of divine vengeance certainly did inspire ferocious reprisals on clearly distinguished "heretical" targets. Catholic noble officers and soldiers could see their bellicose acts as vengeance that responded directly to prior Calvinist violence. At various points during the religious wars, Huguenot crowds and troops performed iconoclasm, overthrew city governments, seized fortifications, dismantled churches and monasteries, pillaged communities, murdered priests, and massacred Catholic civilians and troops. ${ }^{147}$ Such violent acts outraged devout Catholics and inspired retaliation by the soldiers of God, as humble agents of a vengeance that was ultimatlely God's alone.

\section{God's Vengeance and Divine Punishment}

The re-establishment of the "true" faith would be accomplished by the work of soldiers of God who implemented His vengeance on heretics, witches, and irreligious persons. Catholics had formulated articulated notions of divine vengeance during the wars of the Catholic League, including the famous arguments of Jean Bodin. ${ }^{148}$ The gradual restoration of Gallicanism after the Edict of Nantes invested the king with more responsibility than ever for suppressing heresy and inflicting God's vengeance. Many Catholics imagined warfare as divine punishment for the presence of heresy in French society, 
seeing the destruction inflicted on Huguenot-controlled towns as the starkest evidence of God's vengeance.

Early seventeenth-century Catholics believed that divine vengeance could purify government institutions and sacred spaces in France. The 1617 coup d'état against Marie de Médicis' favorite Concino Concini offers fascinating evidence of Counter-Reformation Catholic notions of God's unwillingness to tolerate bad government and irreligiosity. Many French Catholics regarded the killing of the "tyrant" Concini in the courtyard of the palais du Louvre as divine vengeance. Although Concini had lived his life as a Catholic and his body was given a Catholic burial within Saint-Germain-l'Auxerois church in Paris, a crowd of scandalized Parisians disinterred Concini's body as polluting the sacred space of the church. The crowd proceeded to parade the body through the streets of Paris and mutilate it in the place de Grève, site of public executions in the city. ${ }^{149}$ Some Parisian Catholics suspected Concini and his wife, Leonora Galagaï, of being demonically possessed and exercising an evil influence over the young king. Concini's supposed crimes included Judaism and sorcery, in addition to corruption and abuse of power. ${ }^{150}$ After her husband's death, Galagaï was tried and convicted of lèse-majesté divine et humaine, then executed in a public demonstration of God's vengeance on a dangerous witch who had threatened to destroy the French monarchy. 151

Participants in the French Wars of Religion saw combat as a dramatic enactment of God's vengeance. The sudden and explosive violence of battles graphically revealed God's will in human blood. At the battle of Île-de-Riez in April 1622, the late arrival of Protestant ships to rescue Huguenot troops was seen as "a just judgment of God against these heretical rebels, who having dared in this way to save themselves. All the rest [of them] were in the port crying 'mercy' and throwing themselves into the sea to avoid the fury of the soldiers, who one can never prevent from killing in boarding....In the end, the fury calmed, we took around two thousand prisoners, who were sent to the galleys by the king." 152 Louis XIII's initial reaction to his army's victory at Île-de-Riez recognized the divine guidance that he believed he had received: "as it is God who led me and who denied grace to those who looked to the sea for their salvation, it is reasonable that we render thanks to him. I have ordered a Te deum in all the cathedral churches of this kingdom."153 Public ritual celebrations of God's vengeance united militant Catholics in a common notion of cause.

Similarly, divine vengeance was at work at the Île-de-Ré, destroying the Huguenot and English troops attempting to relieve the siege of La Rochelle in 1627. The Tuscan ambassador to France, Giovan Battista Gondi, reported 
the news of the battle of Île-de-Ré, and his corrrespondence provides an intriguing window into Counter-Reformation conceptions of divinity in this period. The victory seemed to be a sign from God and an example to all of Europe, which might soon conform to God's "holy service."154 Gondi hoped that the battle might solidify the relations between France and Spain, since "from this war, God wants to extract this great good for Christianity of the good union of the two most powerful faithful kings." The ambassador also appreciated the significance of the victory for French Catholics, claiming that: "one recognizes the express miracle of God, and the downfall that will be given to heresy in this kingdom — and to rebellion—because, in sum, the capture of La Rochelle is taken for certain.” God was clearly protecting the king from the "dangers of war and the ambushes of traitors," Gondi suggested. The ambassador also described how French Catholics responded to the news of the victory, reporting that many Parisians "shut themselves in to make frequent orations and with such devotion, and who I see still in the masses every morning with tears in their eyes, and raising their hands high.” Parisians Catholics focused on the figure of the king, and his ordeals in recent illnesses and battles. According to Gondi, "everyone truly says that... he has lifted up his mind so much toward God that he lives the life of a saint." The victory thus confirmed Louis XIII's religiosity, and the Tuscan ambassador suggested that "it may mean seeing another Saint-Louis."155 Many devout French Catholics indeed viewed their king as a saintly monarch who was emulating his celebrated predecessor by leading a holy crusade to inflict God's vengeance.

Sieges served as sites of divine punishment on the communities of heretics and sinners. Numerous cities and towns were subjected to the ordeal of siege warfare during the civil wars of the 1610s and 1620s. A Catholic soldier at the siege of Chomerac observed that the hesitancy of the Protestant defenders to negotiate a capitulation after the city walls had been breeched was a sign of God's impending vengeance. For, he argued, "these miserable persons show us that when God wants to punish someone, he first takes away their judgment." In the end, Chomerac did surrender, and the following day a number of the Huguenot defenders were executed as rebels. What impressed the Catholic author of this account was what he regarded as the obstinancy of the Calvinists, who did not "dispose their souls” before death. ${ }^{156}$ Many Huguenot communities suffered even more frightful demonstrations of divine vengeance. During the 1621-1622 civil war, Catholic armies burned the towns of Monheur and Tonneins, and massacred the inhabitants of Négrepelisse in a massive display of divine and royal vengeance. ${ }^{157}$ 
The fall of the Huguenot city of La Rochelle in October 1628 heralded the final enactment of God's wrath on southern French Catholics. La Rochelle had endured a brutal year-long siege that left roughly two-thirds of its population dead or refugees. Meanwhile, Catholic nobles in Vivarais had long awaited the punishment of the "heretics" of Privas, one of the principal Huguenot towns in Languedoc. Privas' Protestant residents had carried out the destruction of the château de Privas in 1619, triggering a new outbreak of civil warfare in the area. A Catholic from the region argued that, "One can not understand this without believing assuredly that God will not leave these crimes unpunished, since from such bad starts always come bad endings.” 158 The same commentator also saw Privas' inhabitants as responsible for the disorders in the 1620s, predicting that: "one day there will be an example through the punishment that God will apply there most justly." 159 As Catholic forces finally began to envelop Privas in 1629, some Protestant troops attempted to escape from the encirclement. One of the Catholic commanders, deciding that he did not have enough troops on hand to block the Huguenots' escape, remarked: "let them go, God must punish Privas and deliver us." 160 The Catholic envelopment of Privas soon tightened, as additional Catholic forces arrived with artillery and began digging siegeworks.

The spectacular destruction of Privas in 1629 was widely regarded by French contemporaries as divine punishment on heretics who had dared to oppose God's authority. One of the Catholic soldiers in the victorious army described the destruction: "The soldiers of the king sacked, pillaged, and burned the town completely, tearing to pieces all those [the inhabitants] that they encountered....it was a clear mark of the wrath of God on this rebel town." ${ }^{161}$ He went on to justify the destruction of Privas in these terms: "here is the punishment that this rebel town merits, and the just punishment that it feels from the hand of God and the arms of the king, for having always been the retreat of those of the Huguenots who lit the fire of rebellion in Languedoc, Vivarais, and Dauphiné."162 The cataclysmic destruction of Privas evoked the purifying flames that had engulfed Sodom and Gomorrah after their inhabitants had provoked God's wrath. ${ }^{163}$ For Counter-Reformation Catholics, the devastation of Privas represented the implementation of divine justice both as a retribution against Calvinist "heretics" and as a just settlement allowing the re-establishment of the Catholic church in Vivarais after decades of Huguenot domination. 


\section{God's Peace and His Church}

Despite the massive destruction wrought by an angered God, CounterReformation Catholics paradoxically also considered God to be the bringer of peace. Devout Catholics passionately proclaimed the power of divine love, believing that God desired peace and that His plan would eventually bring concord to earth. His unconditional love of humans was absolute, according to Catholics, and God was thus considered the ultimate motivator and guarantor of peace agreements. Indeed, the Edict of Nantes's preamble praised and glorified God for having brought about the peace settlement:

\footnotetext{
Among the infinite graces which it has pleased God to bestow on us, this is certainly one of the most notable and remarkable: to have given us virtue and strength to withstand the frightful troubles, confusions, and disorders which prevailed at our accession to this kingdom, which was divided into so many parties and factions, of which that which supported the legitimate government was the smallest; and nevertheless to so have strengthened us against this difficulty, that we have at length surmounted it, and have now reached a harbor of safety and repose for this state. ${ }^{164}$
}

This vision of God's pacificatory role was not a unique feature of the Edict of Nantes, but an aspect of almost all truces and peaces during the religious wars. ${ }^{165}$ French Catholics struggled to reconcile their view that God willed them to fight against Protestants with their belief that God ultimately wanted peace.

If divine aspirations for concord were clear, God's peacemaking gestures were not always easy to discern. During the long decades of religious warfare in the sixteenth and early seventeenth centuries, numerous civil conflicts pitted groups of Catholics against other Catholics. While attention has been paid to these dynamics in the Catholic League period, attempts to conceive of Catholic religious politics in terms of two Catholic "parties," Catholic Leagueur and politique, have arguably obscured more than they have clarified. The vast Catholic majority-perhaps 80 percent of the French population-could not be expected to agree on all issues of religious politics, and the problem of achieving peace among Catholics in France was extremely complicated throughout the religious wars. In the latter stages of the conflict, many Catholics expressed uncertainty over the sincerity of Henri de Navarre's 1593 conversion from Calvinism to Catholicism. Conflict between the French and Spanish kings, two of the great champions of Catholicism in Europe, troubled many Catholics. Some Counter-Reformation Catholics were excited about the possibility of the "Spanish Marriages" in the 1610s uniting French and Spanish monarchies in a double matrimonial bond, but 
others feared Spanish domination of the Gallican church. Invocations of God's peace can be seen in correspondence dealing with the peace of Loudun that settled civil conflict among Catholic princes through compromise in 1616. ${ }^{166}$

During the querelles de la mère et du fils, the disconcerting spectacle of civil warfare between the king and the queen mother horrified Catholics and created highly ambiguous situations for faithful believers. Ambassadors at the French court described the confusion among Catholics created by the conflicts dividing the royal family. Traiano Guiscardi, for example, attempted to dispell the "bad impressions" of Marie de Médicis and to justify her actions during the 1618 civil war, seeing words and deeds as contrary. ${ }^{167}$ Catholic nobles attempted to fulfil God's design amid the turbulent politics and chaos of civil warfare in early seventeenth-century France, but were often unsure of the proper actions to be taken. During the 1619 conflict between Louis XIII and his mother, Henri de Lorraine duc de Mayenne wrote to Marie de Médicis: "I pray to God with all my heart, Madame, that he may wish to assist you with his holy inspiration, being unable to contribute to this other than that which is the duty of a good man and most faithful servant of the king."168 The duc de Mayenne eventually provided military and political support for the queen mother, but he carefully attempted to avoid direct conflict with the king.

God's pacific desires could not be easily read in such circumstances, and devout Catholics seem to have been greatly troubled by the deep divisions between Bourbon royal family members and among French Catholics. An Italian observer at the French court suggested during negotiations in 1619 that God did not want the treaty, desiring instead a more firm, lasting agreement. ${ }^{169}$ A clearer path toward reconciliation between Marie de Médicis and Louis XIII opened after the king's army won a victory at the battle of Pontsde-Cé in 1620. The Tuscan ambassador forwarded news of the initial reunion of the queen mother with her son: "We continue in the common rejoicing at the happy reconciliation of the king with the queen his mother, hoping that God will favor it, conserving it inviolable and perpetual. This is the desire of the son and the mother, who testify to it by the words at their interview."170 Months of negotiations and successive reconciliation ceremonies were necessary before God could be seen as decisively bringing peace between the queen mother and Louis XIII. Marie de Médicis was pleased when she could finally communicate "the joy that God has given me" in restoring their relationship."171

There were even more severe inherent contradictions in any peace agreement with heretics, since such a treaty could be challenged as not 
bringing God's peace. The efforts at reconciliation and coexistence between Catholics and Calvinists in southern France also drew on these notions of a pacific God. During discussions concerning a possible peace agreement in 1622, Claude Bullion wrote to Henri de Rohan duc de Rohan, the principal Protestant military leader in southern France, saying: "I hope that God will bless your interview and that His Majesty will receive the contentment that he promises himself for the good of his kingdom."172 When a compromise agreement was eventually reached, some Catholics remained discontented, but the Protestant-controlled city of Montpellier did have to open its gates to the king's army and submit to the installation of a Catholic garrison.

Many Catholics were convinced that, however desirous God might be of concord among his people, He did not want any peace with heretics. Olivier Christin demonstrates the depth of Catholic opposition to the 1563 pacification of Amboise, which then served as a model for subsequent peace agreements during the religious wars. ${ }^{173}$ Many French Catholics had opposed Michel de l'Hospital's efforts at reconciliation with Protestants during the 1560s, mocking him by asking God to save them from the "Chancellor's mass," meaning a mass in which "some adherents of the Reformed faith continued to attend in order to avoid being declared heretic."174 Later attempts at confessional reconciliation in France brought similar suspicions of peace agreements, as militant Catholics continually challenged any agreement requiring them to accept the polluting presence of Calvinists within Catholic communities. Catholics seem to have seen the bloody 1572 Saint Bartholomew's Day Massacre as a royal-sanctioned execution of seditious Huguenot leaders, which offered proof that negotiating with Calvinists was against God's will. Sylvie Daubresse shows that the parlement de Paris at this time viewed its role as a "sword against heresy," protecting the king and French society from dangerous accommodations with heretics that might undermine royal authority and legal prerogatives. ${ }^{175}$ The Edict of Nantes initially met with serious Catholic opposition, but gained acceptance as Catholics learned how to use the edict to advance Counter-Reformation programs and aims. ${ }^{176}$ While some historians have recently stressed the possibilities of coexistence between Protestants and Catholics in France, they do so primarily by examining the period between the end of full-scale religious warfare in 1629 and the beginning of the infamous dragonnades under Louis XIV. ${ }^{177}$ During the early seventeenth century, Catholic agitation for the re-establishment of their church made an uneasy cohabitation with Calvinists difficult and prevented any real toleration from arising in southern France.

While Catholics were often angered by the provisions protecting Huguenots in many of the peace agreements during the religious wars, the 
peace of Alès in 1629 represented a peace resolution that most Catholics could readily embrace. Following the sack of Privas, a whole succession of Protesant towns and cities in southern France capitulated to Catholic armies. The peace ended hostilities and confirmed the restoration of Catholicism throughout the kingdom of France. ${ }^{178}$ Catholic soldiers entered Montauban, the last major Calvinist-controlled city, following the agreement. Louis XIII and his Catholic troops dictated a peace that effectively ended religious warfare, opened Huguenot towns to Catholic missionaries, favoured Catholic institutions within mixed-religion communities, and fully restored Catholic practice throughout the kingdom. ${ }^{179}$

\section{Conclusion}

Catholic notions of an active divinity gave great strength to the CounterReformation movement and its mission of restoring the mass and rebuilding churches in early seventeenth-century France. Lay Catholics who felt motivated by the Holy Spirit engaged in religious patronage, participated in monastic foundations, and supported conversion efforts. The desire to promote re-Catholicization and to restore the Catholic church in southern France fueled religious conquests to take control of religious sites and urban space in God's name. Catholicism was restored largely through violence during the wars of the 1610s and 1620s, and the zealousness that motivated Catholics sometimes led to atrocities and massive destruction. Thereafter, Calvinism would be confined to a marginal status as a minority religion. Even where Huguenots represented a local majority of the population, they were forced to accept the presence of Catholic churches, clergy, bishops, monasteries, missionaries, and lay people. The period from 1598 to 1629 thus represented a distinct phase in the history of French Catholicism, in which Catholic religiosity was closely linked to violence, but simultaneously to an optimistic vision of successful reform and restoration.

Catholic conceptions of God in this period motivated and sustained a potent Counter-Reformation movement that sanctioned and glorified violence as a means to re-establish the "true" faith within France. Denis Crouzet's mammoth study of the French Wars of Religion has re-situated God at the centre of the religious struggles in France. Crouzet refers to a "pure violence" emanating directly from God, in which combatants could see themselves embroiled in "combats for God, with God, in God." 180 Crouzet depicts both French Catholics and Calvinists as adopting relationships to the divine in terms of violence, although these relations were constructed from differing theological and practical points of view. This approach to God's 
role in French society allows intriguing new interpretations of the motives for the Saint Bartholomew's Day Massacre and of the dynamics of violence during the wars of the Catholic League period of the 1580s. However, this approach seems to minimize the role of human agency by ascribing all violence to apocalyptic visions and underestimating the complex and contradictory ways in which Catholics interpreted God's will. Crouzet's analysis ultimately provides an unsatisfying, and overly tidy, conclusion that God was essentially restored with the assassination of Henri IV, the re-establishment of Gallicanism, and the development of absolutism. ${ }^{181}$ Examining the civil violence after 1598 reveals shifting—but still compelling—religious motives for violence among French Catholics. Devout Catholics in some other areas of Europe may have remained largely passive, but Catholic lay people in France played very active roles in the ongoing conflicts over religion. ${ }^{182}$

Early seventeenth-century lay Catholic conceptions of God and divine presence also reveal the contradictions within the Counter-Reformation movement in France. Catholic desires for the annihilation of heresy clashed with their understanding of God's forgiveness and compassion. Displays of God's vengeance and of His pacific benevolence created tensions among the expectant Catholic faithful, who could not always understand the timing and character of His revelations. God was present and omnipotent, but at times his will seemed inscrutable, creating varying positions among lay Catholics seeking to fulfill his plan. While God at times inspired a "pure violence" from Catholics believers, Catholic relationships to the divine were more varied and complex than the totalizing view presented by Crouzet. The ways in which the participants in religious violence discussed God demonstrate that lay religiosity continued to shape the dynamics of religious violence long after the Edict of Nantes, but never in a univocal manner.

The experience of Henri II de Montmorency, duc de Montmorency, reveals the contradictory and paradoxical nature of Counter-Reformation Catholic lay religiosity and political causes in the early seventeenth century. He had supported the regency and the king in the 1610s, then prudently avoided open support for Marie de Médicis in her conflicts with Louis XIII in 1618-1620. Throughout the 1620s, the duc de Montmorency had been an enthusiastic soldier of God and faithful dévot, fighting at the sieges of Montauban, Montpellier, and Privas. When the flight of Marie de Médicis and Gaston de Bourbon, duc d'Orléans, triggered another civil conflict in 1631-1632, Montmorency sided with Gaston de Bourbon against Cardinal Richelieu. Distressed Catholics in southern France divided over whether or not to support the ducs de Montmorency and d'Orléans. The "rebellion" quickly collapsed after the duc de Montmorency was captured at the battle 
of Castelnaudary in October 1632 and executed in Toulouse. Yet, many of Montmorency's Catholic contemporaries continued to see him as a champion of the faith, and Toulousain Catholics debated how to memorialize him as a fallen hero. ${ }^{183}$ Montmorency's secretary and memoirist depicted his death as a noble sacrifice: "God wanted that his death should be as admirable as his life; that his last actions should crown all the others; and that his Christian virtues would cast off even more brilliance than that of [all] the heroes." 184 God could call even his most bellicose servants to offer their lives for his peace and the king's justice.

The 1632 civil war thus ironically demonstrated the strength of the Counter-Reformation movement in southern France and confirmed the restoration of Catholicism that had been accomplished in the early seventeenth century. The duc de Montmorency's sacrifice illustrates CounterReformation attitudes toward violence and the restoration of the "true" church. The unwillingness of Huguenots to challenge the 1629 peace of Alès and enter civil conflict a mere three years after its implementation signaled that full-scale religious wars had indeed ended. At the same time, despite the death of Montmorency and the punishment of his followers in Languedoc, the Catholic restoration in southern France could not be undermined even by serious political disruptions and divisions among Catholics. While the process of eradicating "heresy" was not completed by 1629, Catholic lay participants in early seventeenth-century conflicts had successfully promoted a particular religious politics of Catholic revival that significantly influenced the political culture of the period. Southern French lay Catholics felt that God had recognized their piety and granted their desires for the re-establishment of Catholic practice throughout southern France.

\section{Northern Illinois University}

\section{Notes}

1. I sincerely thank the two readers who provided excellent comments and suggestions on a previous draft of this article. I would also like to thank Alan Shepard for his support and his suggestions on the development of this project. Research for this article was made possible by the generous funding of the National Endowment for the Humanities and the support of the Medici Archive Project. Any views, findings, conclusions, or recommendations expressed in this publication do not necessarily represent those of the National Endowment for the Humanities.

2. Nicolas Le Cornu de la Courbe was the bishop of Saintes celebrating mass in La Rochelle in 1599. Conradus Eubel, et al, Hierarchia catholica medii et recentoris aevi sive summorum pontificum, S.R.E. cardinalium, ecclesiarum antistitum series, 7 vols. (Padova: Monasterii Regensbergianae, Regensburg \& Il Messagero di S. Antonio, 1898-1968). 
170/ Renaissance and Reformation / Renaissance et Réforme

3. François de Sales quoted in Mack P. Holt, The French Wars of Religion, 1562-1629 (Cambridge: Cambridge University Press, 1995), p. 165.

4. Le Restablissement, \& celebration de la Saincte Messe, \& seruice de Dieu, selon l'Eglise Catholique Apostolique Romaine: en la ville de la Rochelle. Et ladicte Celebration faicte par Mõseigneur le Reuerendiss. Euesque de Xaintes: le Dimanche huictiesme d'Aoust, M.D.XCIX (Lyon: Thibaud Ancelin and Guichard Jullieron, 1599).

5. Since Natalie Zemon Davis’s influential 1973 article on "rites of violence" successfully foregrounded the religious dimensions of crowd violence in such incidents as the Saint Bartholomew’s Day Massacre of 1572, historians have increasingly "put religion back into" the history of the French Wars of Religion. See: “The Rites of Violence,” in Natalie Zemon Davis, Society and Culture in Early Modern France (Stanford: Stanford University Press, 1975), pp. 152-87; Mack P. Holt, "Putting Religion Back into the Wars of Religion,” French Historical Studies 18 (Fall 1993), pp. 524-51. On the debate over religion's role in the French Wars of Religion, see: Henry Heller, "Putting History Back into the Religious Wars: A Reply to Mack P. Holt,” French Historical Studies 19 (Spring 1996), pp. 853-61; Susan Rosa and Dale K. Van Kley, "Religion and the Historical Discipline: A Reply to Mack Holt and Henry Heller,” French Historical Studies 21 (Autumn 1998), pp. 611-29.

6. See Penny Roberts's important work on contested religious sites in the earlier religious wars: Penny Roberts, "The Most Crucial Battle of the Wars of Religion? The Conflict over Sites for Reformed Worship in Sixteenth-Century France,” Archiv für Reformationsgeschichte 89 (1998), pp. 247-67.

7. Thierry Wanegffelen, ed., De Michel de l'Hospital à l'édit de Nantes. Politique et religion face aux églises (Aubenas: Presses Universitaires Blaise-Pascal, 2002). Paul Mironneau and Isabelle Pébay-Clottes, eds., Paix des armes, paix des âmes. Actes $d u$ colloque international tenu au Musée national du château de Pau et à l'Université de Pau et des Pays de l'Adour (Paris: Imprimerie National Éditions, 2000); Guy Saupin, Rémy Fabre, and Marcel Launay, eds., La Tolérance : Colloque international de Nantes mai 1998. Quatrième centenaire de l'édit de Nantes (Rennes: Presses Universitaires de Rennes et Centre de Recherche sur l'Histoire du Monde Atlantique, 1999); Richard L. Goodbar, ed., The Edict of Nantes: Five Essays and a New Translation (Bloomington: The National Huguenot Society, 1998); Michel Grandjean and Bernard Roussel, ed., Coexister dans l'intolérance. L'édit de Nantes (1598) (Geneva: Labor et Fides, 1998); Jannine Garrison, L'édit de Nantes (Biarritz: Éditions Atlantica, 1997); Bernard Cottret, L'édit de Nantes. Pour en finir avec les guerres de religion (Paris: Perrin, 1997); Olivier Christin, La paix de religion. L'autonomisation de la raison politique au XVIe siècle (Paris: Seuil, 1997).

8. Jérémie Foa, "Making Peace: The Commissions for Enforcing the Pacification Edicts in the Reign of Charles IX (1560-1574),” French History 18, 3 (2004), pp. 256-74; Raymond A. Mentzer, "The Edict of Nantes and its Institutions," in Society and Culture in the Huguenot World, 1559-1685 (Cambridge: Cambridge University Press, 2002), pp. 98-116; Marc Venard, "Un édit bien enregistré. Le quatrième centenaire de l'édit de Nantes,” Revue d'Histoire de l'Église de France 87 (January-June 2001), pp. 27-45.

9. For an overview of this literature, see: Mack P. Holt, "The Social History of the Reformation: Recent Trends and Future Agendas,” Journal of Social History 37 (Fall 2003), pp. 133-44. 
10. The scope of early modern devotional activity can be seen in the variety of popular religious movements. For example, Richard Strier refers to "devout humanism" as "a movement that set out to show Christianity to be fully possible within the bounds of ordinary and recognizable aristocratic life.” Richard Strier, "Sanctifying the Aristocracy; 'Devout Humanism' in Francois de Sales, John Donne, and George Herbert,” Journal of Religion 69 (January 1989), p. 37.

11. Lee Palmer Wandel, Voracious Idols and Violent Hands: Iconoclasm in Reformation Zurich, Strasbourg, and Basel (Cambridge: Cambridge University Press, 1994), pp. 1-7. Wandel's approach is strongly influenced by interpretations of the Reformation focusing on cultural history and religious practice, including works by Robert Scribner, Eamon Duffy, R. Po-chia Hsia, Natalie Zemon Davis, and Pierre Chaunu.

12. I use the term "Counter-Reformation" to refer specifically to Post-Tridentine Catholic movements intent on halting the spread of Protestantism and advancing re-conversion efforts. The Counter-Reformation, as I understand it, represented only one of a series of Catholic renewal and revival movements. For a discussion of debates surrounding Catholic Reformation terminology, see: Barbara B. Diefendorf, From Penitence to Charity: Pious Women and the Catholic Reformation in Paris (Oxford: Oxford University Press, 2004), p. 270, fn 272; John W. O’Malley, Trent and All That: Renaming Catholicism in the Early Modern Era (Cambridge: Harvard University Press, 2000); H. Outram Evenett, The Spirit of the Counter-Reformation, ed. John Bossy (Notre Dame: Notre Dame University Press, 1968).

13. This article represents an outgrowth of archival research done in preparing my forthcoming book, entitled Heroic Souls: French Nobles and Religious Violence after the Edict of Nantes, for publication. I had initially hoped to compare Catholic and Calvinist notions of God in this article, but the resulting piece would have been too long. I have thus decided to deal with the complexities of the Huguenot relationship to the divine in this period in a separate article.

14. See: "The Edict of Nantes with Its Secret Articles and Brevets," in The Edict of Nantes: Five Essays and a New Translation, ed. Richard L. Goodbar (Bloomington: National Huguenot Society, 1998).

15. Henri IV’s instructions cited in Marc Venard, "L’église catholique bénéficiaire de l'édit de Nantes. Le témoignage des visites épiscopales,” in Coexister dans l'intolérance, p. 283.

16. Archives Communales [hereafter, AC] Montauban, 19 GG 1, liasse 36, no. 82; and liasse 97.

17. On the aspects of the Edict of Nantes dealing with peace with the duc de Mercœur in Bretagne, see: James B. Collins, "Les états de Bretagne et l'édit de Nantes: La mémoire retrouvée,” in Paix des armes, paix des âmes, pp. 269-85.

18. Bernard Barbiche, "L’édit de Nantes et son enregistrement. Genèse et publication d'une loi royale,” in Paix des armes, paix des âmes, pp. 251-60; Gabriel Audisio, "La réception de l'édit de Nantes en Provence (1598-1602),” in Coexister dans l'intolérance, pp. 26782.

19. Thierry Issartel, “L'état et la tolérance religieuse en Béarn (1599-1620),” in Paix des armes, paix des âmes, pp. 313-32.

20. Christian Desplat, “Henri IV « Roi De Paix », dans l’historiographie d'ancien régime,” in Paix des armes, paix des âmes, pp. 405-25; Hubert Bost, “Élie Benoist et l’historiographie 
172/ Renaissance and Reformation / Renaissance et Réforme

de l'édit de Nantes," in Coexister dans l'intolérance, pp. 371-84; Venard, “L'église catholique bénéficiaire de l'édit de Nantes,” pp. 283-84.

21. Françoise Chevalier, "Les difficultés d'application de l'édit de Nantes d'après les cahiers des plaintes (1599-1660),” in Coexister dans l'intolérance, pp. 303-20.

22. Stéphane Capot, "La paix vécue à Castres au temps de l'édit de Nantes (1595-1670)," in Paix des armes, paix des âmes, pp. 303-12; Raymond A. Mentzer, "L'édit de Nantes et l'établissement de la paix en Languedoc,” in Paix des armes, paix des âmes, pp. 295301; Raymond A. Mentzer, "L'édit de Nantes et la chambre de justice du Languedoc,” in Coexister dans l'intolérance, pp. 321-38; Stéphane Capot, Justice et religion en Languedoc au temps de l'édit de Nantes. La chambre de l'édit de Castres (1579-1679) (Paris: École des Chartes, 1998).

23. Katharine J. Lualdi, "Persevering in the Faith: Catholic Worship and Communal Identity in the Wake of the Edict of Nantes,” Sixteenth Century Journal 35 (2004), p. 733.

24. A series of studies on the implementation of the edict have revealed some of the common issues and local variations in the application of the Edict of Nantes in different provinces. Such regional approaches include: Audisio, pp. 267-82; Michel Cassan, Le temps des guerres de religion. Le cas du Limousin (vers 1530-vers 1630) (Paris: Publisud, 1996).

25. “Ordonnance de Anne de Levy duc de Ventadour, 25 February 1612” (Béziers: Jean Pech, 1612), Archives Départementales [hereafter, AD] Hérault, C 8406.

26. Associations of God with king were arguably less about divine-right "absolutism" than about identifying the king with the suppression of heresy.

27. Jotham Parsons, The Church in the Republic: Gallicanism and Political Ideology in Renaissance France (Washington, D.C.: Catholic University of America Press, 2004); Sylvie Daubresse, Le parlement de Paris ou la voix de la raison (1559-1589) (Geneva: Librairie Droz, 2005), pp. 203-42, 465-76.

28. Venard, “L’église catholique bénéficiaire de l’édit de Nantes,” pp. 283-302.

29. Élisabeth Rabut, “Vie de foi et vie de la cité: L’exécution de l'édit de Nantes en Dauphiné,” in Paix des armes, paix des âmes, pp. 287-94.

30. On this point, I disagree with S. Amanda Eurich's vision of armed conflict ceding to a "war of words." S. Amanda Eurich, "La politique de la différenciation: Controverse et conversions en Béarn au XVIIe siècle,” in Paix des armes, paix des âmes, pp. 333-42.

31. "Minutte dune harangue que le roy avoit commandé au feu sr du Vair pour la faire au parlement de Thle pensant y aller de Cleirac sans s'arrester a Montauban en juillet 1621,” Bibliothèque Nationale de France [hereafter, BNF], Dupuy 100, f 56-66.

32. Toward the beginning of the sixteenth century, European society had experienced what some historians have described as an "age of anxiety," which inspired a series of religious revival and reform movements in the Latin Christian church. Increasingly radical reconsiderations of Christian theology, belief, and practice had thrown the very notion of God into flux.

33. Eamon Duffy, The Stripping of the Altars: Traditional Religion in England, 1400-1580 (New Haven: Yale University Press, 1992), p. 4.

34. David Nicholls, "France," in The Early Reformation in Europe, ed. Andrew Pettegree (Cambridge: Cambridge University Press, 1992), pp. 120-41; Donald R. Kelley, The Be- 
ginning of Ideology: Consciousness and Society in the French Reformation (Cambridge: Cambridge University Press, 1981).

35. Davis, “The Rites of Violence,” pp. 156-57.

36. Marc Venard, “Catholicism and Resistance to the Reformation in France, 1555-1585,” in Reformation, Revolt and Civil War in France and the Netherlands, 1555-1585, ed. Philip Benedict, et al. (Amsterdam: Royal Netherlands Academy of Arts and Sciences, 1999), pp. 133-48.

37. Robert A. Schneider, Public Life in Toulouse, 1463-1789: From Municipal Republic to Cosmopolitan City (Ithaca: Cornell University Press, 1989), pp. 167-74.

38. For examples of convergences between bon français and bon catholique positions, see: Manifeste des bons françois, sur la mort desplorable de monseigneur le mareschal de Schombert. Dedié a madame la mareschalle de Schombert (Paris: Jean Brunet, 1632),

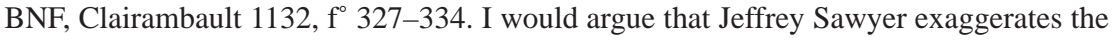
opposition between bon françois and dévot ideas in portraying them as "parties." Jeffrey K. Sawyer, Printed Poison: Pamphlet Propaganda, Faction Politics, and the Public Sphere in Early Seventeenth-Century France (Berkeley: University of California Press, 1990), pp. 94-95.

39. The majority of the manuscript sources consulted are conserved in the Bibliothèque Nationale de France, in the Archives Nationales, and in various Archives Départementales and Archives Municipales in southern France. Letters from the French court to Tuscany have been examined at the Archvio di Stato di Firenze. On livres de raison, see: Sylvie Mouysset, "De père en fils: Livre de raison et transmission de la mémoire familiale (France du sud, XVe-XVIIIe Siècle,” in Religion et politique dans les sociétés du Midi, ed. Nicole Lemaitre (Toulouse: Éditions du CTHS, 2002), pp. 139-51.

40. Michel Pernot, "L’inspiration religieuse de Jacques Callot,” in Jacques Callot. Musée historique lorrain, Nancy, 13 juin-14 septembre 1992, ed. Paulette Choné (Paris: Éditions de la Réunion des musées nationaux, 1992), pp. 433-43.

41. François de Sales, Introduction à la vie dévote (Paris: Librairie Victor Lecoffre, 1894 [original, 1608]).

42. Le concert des anges, ou le Père éternel entouré d'anges, Musée des beaux-arts de Rouen, inv. 803-9; Nicolas Sainte Fare Garnot, "Philippe de Champaigne, peintre de Marie de Médicis,” in Le 'siècle' de Marie de Médicis. Actes du séminaire de la chaire rhétorique et société en Europe (XVIe-XVIIe siècle) sous la direction de l'Académie française, Collège de France, 21-23 janvier 2000, ed. Françoise Graziani and Francesco Solinas (Alessandro: Edizioni dell'Orso, 2002), pp. 95-105.

43. Pierre Bérulle, Discours de l'état et des grandeurs de Jésus, par l'union ineffable de la divinité avec l'humanité, in Euvres completes de Bérulle, cardinal de l'église romaine, fondateur et primier superieur de l'Oratoire, ed. Jean-Pierre Migne (Paris: Jean-Pierre Migne, 1856), p. 112.

44. Jacques Callot. Musée historique lorrain, Nancy, 13 juin-14 septembre 1992, ed. Paulette Choné (Paris: Éditions de la Réunion des musées nationaux, 1992), pp. 400-11, 444-89.

45. For accessible translations of these key works of Catholic devotional literature, see: Teresa de Ávila, Life of Saint Teresa of Ávila by Herself, trans. J.M. Cohen (London: Penguin 
174/ Renaissance and Reformation / Renaissance et Réforme

Classics, 2004); Ignatius of Loyola, Personal Writings, trans. Joseph A. Munitiz \& Philip Endean (London: Penguin Classics, 2004); François de Sales, Introduction to the Devout Life, trans. (New York: Vintage Spiritual Classics, 2002).

46. André Chastel, French Art: The Ancien Régime, 1620-1775, trans. Deke Dusinberre (Paris: Flammarion, 1996), pp. 136-42. Philip Conisbee, ed., Georges de La Tour and his World (New Haven: Yale University Press, 1996), pp. 39-52.

47. Virginia Reinburg, "Liturgy and the Laity in Late Medieval and Reformation France," Sixteenth Century Journal 23 (1992), pp. 526-647; Barbara B. Diefendorf, Beneath the Cross: Catholics and Huguenots in Sixteenth-Century Paris (Oxford: Oxford University Press, 1991), pp. 31-36, 45-48. For a key analysis of the significance of the Eucharist in medieval religiosity, see: Caroline Walker Bynum, Holy Feast and Holy Fast: The Religious Significance of Food to Medieval Women (Berkeley: University of California Press, 1987).

48. François Veron, Examen des mysteres de la cene pretendue reformee ou Viandes en peinture, mangées par imagination, servies par les Ministres en leur banquet reformé. Traicté auquel il est monstré, que la Cene de la Religion pretenduë, n'est qu'un ramas d'inventions Ministralles, sans aucun appuy des Escritures Sainctes, ny des Saincts Peres, embroüillé de plusieurs absurditez \& contradictions. Presché à Roüen, en l'Eglise de S. Ouën, le Dimanche des Rameaux, par le P. François Veron Parisien, de la Compagnie de Jesus. Partie premiere qui explique quelle est la viande que mangent les Religionnaires en leur Cene (Roüen : Nicolas Le Prevost, 1618).

49. On visual expressions of God and rationales for iconoclasm, see: Wandel, Voracious Idols and Violent Hands, pp. 26-51; Lee Palmer Wandel, "Envisioning God: Image and Liturgy in Reformation Zurich,” Sixteenth Century Journal 24 (Spring 1993), pp. 21-40.

50. Catholics represented perhaps 40 percent of Montpellier's population around 1609. Philip Benedict, "Confessionalization in France? Critical Reflections and New Evidence," in Society and Culture in the Huguenot World, 1559-1685, ed. Raymond A. Mentzer and Andrew Spicer (Cambridge: Cambridge University Press, 2002), pp. 53-54; Philip Benedict, "Faith, Fortune and Social Structure in Seventeenth-Century Montpellier," in The Faith and Fortunes of France's Huguenots, 1600-85 (Aldershot: Ashgate, 2001), pp. 121-49.

51. André Delort, Mémoires inédits d'André Delort sur la ville de Montpellier au XVIIe siècle (1621-1693) (Marseille: Laffitte Reprints, 1980), vol. 1, p. 6.

52. This polemical work is Le Tombeau de la Messe (Geneva: P. Aubert, 1622).

53. Delort, vol. 1, p. 7.

54. Delort here draws a parallel between the saving of Montpellier and the delivery of Zion from captivity. Delort, vol. 1, pp. 12-13.

55. On Eucharistic processions and the feast of Corpus Christi, see: Diefendorf, Beneath the Cross, pp. 32-33, 44-48.

56. Matteo Bartolini to Cosimo II de’ Medici. Paris, 27 March 1620. Archivio di Stato di Firenze [hereafter, ASF], Mediceo del Principato [hereafter, MdP] 4635, n.p.

57. Delort, vol. 1, p. 46; Schneider, pp. 104-105. 
58. On Catholic conceptions of conversion, see: Michael Wolfe, The Conversion of Henri IV: Politics, Power, and Religious Belief in Early Modern France (Cambridge: Harvard University Press, 1993), pp. 6-21.

59. Declaration et confession de foy, faicte par monseigneur de Candale dans le synode des Eglises reformees des Cevennes \& Gevauldan assemblé en Alez le dimanche dixiesme de janvier 1616. Apres laquelle il fut publiquement reçeu dans l'eglise, à la fin de la predication (Nîmes: Jean Vaguenar, 1616), BNF, Clairambault 1137, f²50-253.

60. Numerous pamphlets celebrated the conversion of the duc de Lesdiguières. For an example, see: Relation veritable et journaliere de tout ce qui s'est passé en France \& Pays Estrangers. Depuis le depart du roy de sa ville Capitale de Paris, jusqu'à present (Paris: Joseph Bouïllerot, 1622), BNF, Clairambault 378, f 150-169. A study of political culture provides context: Hélène Duccini, Faire voir, faire croire. L'opinion publique sous Louis XIII (Seyssel: Champ Vallon, 2003), pp. 392-93. On conversion more generally, consult: Keith Luria, "The Politics of Protestant Conversion to Catholicism in SeventeenthCentury France,” in Conversion to Modernities: The Globalization of Christianity, ed. Peter van der Veer (New York: Routledge, 1996), pp. 23-46.

61. Glenn Burgess, “The Divine Right of Kings Reconsidered,” English Historical Review 107 (October 1992), 837-61. Paul Laurence Rose, "The Politique and the Prophet: Bodin and the Catholic League, 1589-1594,” Historical Journal 21 (December 1978), pp. 783-808.

62. On the king's touch and the king's two bodies, see: Sergio Bertelli, Il Corpo del Re: Sacralità del Potere nell'europa Medievale e Moderna, 2nd ed. (Florence: Ponte alle Grazie, 1995); Ernst Kantorowicz, The King's Two Bodies (Berkeley: California University Press, 1957: 1981); Marc Bloch, Les rois thaumaturges. Etude sur le caractère surnaturel attribué à la puissance royale particulièrement en France et en Angleterre (Paris: Colin, 1923: reprint 1961).

63. One of the most detailed studies of the cycle de-emphasizes religious aspects in its interpretation: Ronald Forsyth Millen and Robert Erich Wolf, Heroic Deeds and Mystic Figures: A New Reading of Rubens' Life of Maria de' Medici (Princeton: Princeton University Press, 1989).

64. Diefendorf, Beneath the Cross, pp. 28-48. Diefendorf, From Penitence to Charity, pp. 27-48.

65. Schneider, pp. 90-131; Carole Delprat, "Les magistrats du parlement de Toulouse durant la Ligue,” Annales du Midi 108 (1996), pp. 39-62; Joan Davies, "Persecution and Protestantism: Toulouse, 1562-1575,” Historical Journal 22 (March 1979), pp. 31-51; Mark Greengrass, “The Sainte Union in the Provinces: The Case of Toulouse,” Sixteenth Century Journal 14 (1983), 469-96.

66. François Estrades to Paul Phélypeaux de Pontchartrain. n.p., 1618, BNF, Clairambault $374, \mathrm{f}^{\circ} 10$.

67. Henri I de Montmorency duc de Montmorency to Marie de Médicis, La Grange-des-Prés, 5 September 1613, BNF, Clairambault 1131, f f 182-183.

68. Lualdi, pp. 717-34.

69. Robert Sauzet, Les Cévennes catholiques. Histoire d'une fidélité, XVIe-XXe siècle (Paris: Perrin, 2002), pp. 84-116. 
176/ Renaissance and Reformation / Renaissance et Réforme

70. Jacques Le Brun, “Théologie et spiritualité,” in Le XVIIe siècle. Diversité et cohérence, ed. Jacques Truchet (Paris: Berger-Levrault, 1992), pp. 218-19.

71. Diefendorf, From Penitence to Charity, pp. 70-71.

72. Dorothy S. Packer, “Collections of Chaste Chansons for the Devout Home (1613-1633)," Acta Musicologica 61 (May-August 1989), pp. 175-216.

73. Diefendorf, From Penitence to Charity, pp. 49-76. For a description of women's ascetic devotional activities in Toulouse, see: Charlotte de Saint-Claire to Cristina di Lorena, Toulouse, 10 July 1635, ASF, 5950, f 569.

74. Joanne Baker, "Female Monasticism and Family Strategy: The Guises and Saint Pierre de Reims,” Sixteenth Century Journal 28 (Winter 1997), pp. 1091-1108.

75. Diefendorf, From Penitence to Charity, pp. 135-138. For a discussion of monastic foundations in southern France, see: Brian Sandberg, "Financing the Counterreformation: Noble Credit and Construction Projects in Southern France during the Early Seventeenth Century," in Acts of the XXXVI Week of Studies at the Istituto Internazionale di Storia Economica 'F.Datini', forthcoming.

76. Jill R. Fehleison, "Appealing to the Senses: The Forty Hours Celebrations in the Duchy of Chablais, 1597-98,” Sixteenth Century Journal 36 (Summer 2005), pp. 375-96.

77. On the revival of Marian devotion in Guyenne, see: Gregory Hanlon, Confession and Community in Seventeenth-Century France: Catholic and Protestant Coexistence in Aquitaine (Philadelphia: University of Philadelphia Press, 1993), pp. 156-161; Gregory Hanlon, "Piété populaire et intervention des moines dans les miracles et les sanctuaires miraculeux en Agenais-Condomois au 17e siècle,” Annales du Midi (1985), pp. 115-27.

78. Marie de Médicis to Ferdinando I de’ Medici, Saint-Germain-en-Laye, 13 August 1603, ASF, MdP 4729, f 81.

79. Marie de Médicis to Cristina di Lorena, Paris, 30 July 1615, ASF, MdP 4729A, f 360.

80. Eric Nelson, The Jesuits and the Monarchy: Catholic Reform and Political Authority in France (1590-1615) (Aldershot: Ashgate, 2005); Robert Bireley, The Jesuits and the Thirty Years War: Kings, Courts, and Confessors (Cambridge: Cambridge University Press, 2003), pp. 77-78.

81. Marie de Médicis to Ferdinando II de’ Medici, Paris, 26 April 1628, ASF, MdP 4729A, $\mathrm{f}^{\circ} 529$.

82. Lisa Silverman, Tortured Subjects: Pain, Truth, and the Body in Early Modern France (Chicago: University of Chicago Press, 2001), pp. 111-30.

83. Brad S. Gregory, Salvation at Stake (Cambridge: Harvard University Press, 1999), p. 276.

84. Nicolas Le Roux, La faveur du roi. Mignons et courtisans au temps des derniers Valois (vers 1547 - vers 1589) (Seyssel: Champ Vallon, 2000), pp. 593-602. For other evidence of self-mortification in the 1570s and 1580s, see: Schneider, pp. 90-131.

85. Wolfe, pp. 159-163.

86. Diefendorf, From Penitence to Charity, pp. 75-76.

87. Gregory, pp. 277-80, 292-94. 
88. Lee Palmer Wandel discusses Gregory's problematic focus on the Henrician martrys in her review of Brad S. Gregory, Salvation at Stake: Christian Martyrdom in Early Modern Europe, in Sixteenth Century Journal 31 (Winter 2000), pp. 1169-72.

89. Allan A. Tulchin, “The Michelade in Nîmes, 1567,” French Historical Studies 29 (Winter 2006), pp. 1-35.

90. Nicolas Poussin, The Martyrdom of Saint Erasmus (1628), Pinacoteca, The Vatican, Rome; André Chastel, French Art: The Ancien Régime, 1620-1775, trans. Deke Dusinberre (Paris: Flammarion, 1996), pp. 142-49.

91. Parsons, pp. 227-73.

92. Parlement de Toulouse to Henri II de Montmorency duc de Montmorency, Toulouse, 20 fevrier 1624, BNF, Clairambault 378, $\mathrm{f}^{\circ} 466$.

93. For an example, see: Anne de Lévis duc de Ventadour to Paul Phélypeaux de Pontchartrain, La Voulte, 7 January 1618, BNF, Clairambault 374, f ${ }^{\circ}$ 8-9.

94. Protestant reformers attempted to limit the scope of God's miracles, although they confirmed that God would continue to work certain types of miracles until the Last Days. Mark Greengrass, "Miracles and the Peregrinations of the Holy in France During the Wars of Religion," in Religious Ceremonials and Images: Power and Social Meaning, ed. José Pedro Paiva (Coimbra: Centro de História da Sociedade e da Cultura and European Science Foundation, 2002), pp. 389-414.

95. Jean de Gaufreteau, Chronique bordeloise (Bordeaux: Charles Lefebvre, 1877-1878), vol. 1, pp. 328-29.

96. Simon Du Cros, Histoire de la vie de Henry dernier duc de Montmorency. Contenant tout ce qu'il a fait de plus remarquable depuis sa naissance jusques à sa mort (Paris: Antoine Sommaville \& Augustin Courbé, 1643), pp. 64-67.

97. Pablo E. Pérez-Mallaína, Spain’s Men of the Sea: Daily Life on the Indies Fleets in the Sixteenth Century, trans. Carla Rahn Philips (Baltimore: Johns Hopkins University Press, 1998), pp. 237-45.

98. La Noue to Paul Phélypeaux de Pontchartrain, Bayonne, 12 January 1616, BNF, Clairambault 366, f ${ }^{\circ} 331-332$.

99. Gregory, pp. 307-14.

100. Delort, vol. 1, pp. 61-62.

101. "Relatione della Presa del Pont de Sèe su la riviera della Loire fatta dall'essercito del Re,” ASF, MdP 4635, n.f.

102. Louis XIII to Hercule de Rohan duc de Montbazon, camp at Sainct Jean d'Angely, 25 June 1621, BNF, Manuscrits français [hereafter, Mss. fr.] 23060, f ${ }^{\circ}$ 21-22.

103. "Dieu a tellement beni son intention, que d'un petit commencement, e, comme on peut dire, d'une mouche, il a faict naistre un elephant. Car c'est aujourd'huy le plus consideré e le plus riche couvent de Bourdeaux.” Gaufreteau, Chronique bordeloise, vol. 2, pp. 21-22.

104. Bernard Dompnier, "Le diable des missionnaires des XVII et XVIII ${ }^{\mathrm{e}}$ siècles," in Les missions intérieurs en France et en Italie du XVI ${ }^{e}$ au XX $X^{e}$ siècle, ed. Christian Sorrel and Frédéric Meyer (Chambéry: Institut d’études savoisiennes, 2001), pp. 233-46. 
178/ Renaissance and Reformation / Renaissance et Réforme

105. Narré de la merveilleuse conversion des heretiques d'Aubenas a nostre saincte foy (Lyon: Louys Muguet, 1628). BNF, $8^{\circ}$ Lb $^{36} 2597$.

106. Mark Juergensmeyer, Terror in the Mind of God: The Global Rise of Religious Violence, updated ed. (Berkeley: University of California Press, 2001), pp. 216-24.

107. Paul DeHart, “The Ambiguous Infinite: Jungel, Marion, and the God of Descartes,” Journal of Religion 82 (January 2002), pp. 75-96.

108. Studies of portents during the religious wars have sometimes concentrated on uses of astrology and monstrosities in Protestant propaganda, downplaying or ignoring Catholic cases. Andrew Cunningham and Ole Peter Grell, The Four Horsemen of the Apocalypse: Religion, War, Famine and Death in Reformation Europe (Cambridge: Cambridge University Press, 2000), pp. 71-77; R.W. Scribner, For the Sake of Simple Folk: Popular Propaganda for the German Reformation, revised ed. (Oxford: Clarendon Press, 1994). Denis Crouzet attempts a balanced reading of pre-Reformation, Catholic, and Calvinist forms of astrology: Denis Crouzet, Les guerriers de Dieu. La violence au temps des troubles de religion (vers 1525 - vers 1610), 2 vols. (Seyssel: Champ Vallon, 1990), vol. 1, pp. 101-53.

109. Cunningham and Grell, pp. 71-79; Hervé Drévillon, Lire et écrire l'avenir. L'astrologie dans la France du Grand Siècle (1610-1715) (Seyssel: Champ Vallon, 1996), pp. 21-66.

110. R. Po-chia Hsia, “A Time for Monsters: Monstrous Births, Propaganda, and the German Reformation,” in Monstrous Bodies/Political Monstrosities, ed. Laura Lunger Knoppers and Joan B. Landes (Ithaca: Cornell University Press, 2004), pp. 83-84.

111. For an introduction to histoires prodigieuses in sixteenth-century France, see: Natalie Zemon Davis, The Return of Martin Guerre (Cambridge: Harvard University Press, 1983), pp. 104-13.

112. Jean de Gaufreteau, Chronique bordeloise (Bordeaux: Charles Lefebvre, 1877-1878), vol. 2, pp. 45-46. Delort, vol. 1, p. 34.

113. For an example of contemporaneous uses of prophesy in New Spain, see: Jorge Canizares Esguerra, "New World, New Stars: Patriotic Astrology and the Invention of Indian and Creole Bodies in Colonial Spanish America, 1600-1650," American Historical Review 104 (February 1999), pp. 33-68.

114. Philip Benedict, "Un roi, une loi, deux fois: Parameters for the History of Catholic-Reformed Co-Existence in France, 1555-1685,” in Tolerance and Intolerance in the European Reformation, ed. Ole Peter Grell and R.W. Scribner (Cambridge: Cambridge University Press, 1996), pp. 65-93.

115. Diefendorf, Beneath the Cross, pp. 150-51.

116. Henri II de Bourbon prince de Condé to Henri de Rohan duc de Rohan, Montpellier, 28 November 1628, BNF, Cinq Cens de Colbert 2, f 169.

117. Revelation 21. All biblical references are to The Bible: Authorized King James Version, (Oxford: Oxford University Press, 1997). On sixteenth- and seventeenth-century interpretations of Revelation, see: Cunningham and Grell.

118. Revelation 12: 7-9.

119. Juergensmeyer, pp. 145-63. 
120. Crouzet, vol. 1, pp. 233-317. This view has been criticized, most recently by: Luc Racaut, Hatred in Print: Catholic Propaganda and Protestant Identity During the French Wars of Religion (Aldershot: Ashgate, 2002), pp. 25-29.

121. Diefendorf, Beneath the Cross, p. 151.

122. R. Scott Appleby, The Ambivalence of the Sacred: Religion, Violence, and Reconciliation (Lanham: Carnegie Commission on Preventing Deadly Conflict and Rowman \& Littlefield, 2000), pp. 8-13.

123. Juergensmeyer, pp. 187-215.

124. Crouzet, vol. 1, pp. 319-410.

125. This dual agency highlights Lee Palmer Wandel's assessment of agency in the history of religions in her review of Brad S. Gregory, pp. 1169-72.

126. Sauzet, pp. 102-105.

127. For examples of priests leading prayers and mass before combat, see: Du Cros, pp. 5156; "Recit veritable de la prise de la ville de Pamiers Capitale du Pays de Foix, ensemble de Beaufort Lieutenant General du duc de Rohan, Dauros gouverneur de Mazeres et desroutte de toutes les troupes de Foix,” BNF, Dupuy 100, f $\mathrm{f}^{\circ}$ 298-301.

128. James B. Wood, The King's Army: Warfare, Soldiers, and Society During the Wars of Religion in France, 1562-1576 (Cambridge: Cambridge University Press, 1996); John A. Lynn, The Bayonets of the Republic: Motivation and Tactics in the Army of Revolutionary France, 1791-94 (Urbana: University of Illinois Press, 1984), pp. 21-40.

129. Lettre escritte a monsieur le duc d'Hallvin, sur la mort de monsieur le mareschal de Schonberg (Paris: n.p., 1632). BNF, Clairambault 1132, fo 302-319.

130. États de Languedoc to Henri II de Montmorency, duc de Montmorency, Pézenas, 27 January 1632, AD Hérault, A 44, f 121 . Ironically, Montmorency’s participation in civil warfare the same year would cost him his life and remove a strong supporter of the Counter-Reformation in Languedoc.

131. On French noble participation in confraternities, see: Schneider, pp. 111-21; Roberg R. Harding, Anatomy of a Power Elite: The Provincial Governors of Early Modern France (New Haven: Yale University Press, 1978), pp. 55-67.

132. Franco Angiolini, I cavalieri e il principe (Firenze: EDIFIR Edizioni Firenze, 1996), pp. 147-48; Brian Sandberg, “"Through Naval Practice and the Association with Foreigners': French Nobles’ Participation in Mediterranean Religious Struggles, 1598-1635,” Journal of Mediterranean History (forthcoming).

133. For an example of a noble’s expression of his desire to serve in Malta, see: BNF, Mss. fr. $3722, f^{\circ} 3$.

134. Louis de Chabans, Histoire de la guerre des Huguenots faicte en France sous le regne du roy Louys XIII avec les plans des sieges des villes en taille douce. Par monsieur le baron de Chabans, gentil'homme ordinaire de la chamber du roy, gouverneur de Saincte Foy, \& general de l'artillerie de la serenissime republique de Venise (Paris: Toussainct du Bray, 1634), pp. 572-73.

135. Henri de Schömberg comte de Nanteuil to Paul Phélypeaux de Pontchartrain, Limoges, 5 April 1619, BNF, Cinq Cens de Colbert 97, f 177. 
180/ Renaissance and Reformation / Renaissance et Réforme

136. Brian Sandberg, “'The Magazine of All their Pillaging’: Armies as Sites of Second-Hand Exchanges during the French Wars of Religion," in Alternative Exchanges: Second-Hand Circulations from the Sixteenth Century to the Present, ed. Laurence Fontaine (Oxford: Oxford University Press, forthcoming). For discussions of "military entrepreneurs" and noble credit in early modern war finance, see: John A. Lynn, Giant of the Grand Siècle: The French Army, 1610-1715 (Cambridge: Cambridge University Press, 1997), pp. 24 30, 180-83; David Parrott, Richelieu's Army: War, Government and Society in France, 1624-1642 (Cambridge: Cambridge University Press, 2001), pp. 225-46; John A. Lynn, "How War Fed War: The Tax of Violence and Contributions during the grand siècle," Journal of Modern History 65 (June 1993), pp. 286-310; Geoffrey Parker, The Army of Flanders and the Spanish Road, 1567-1659: The Logistics of Spanish Victory and Defeat in the Low Countries' Wars (Cambridge: Cambridge University Press, 1972), pp. 48-49; Fritz Redlich, The German Military Enterpriser and his Work Force: A Study in European Economic and Social History, 2 Vol. [Vierteljahrschrift für Sozial-und Wirtschaftgeschichte. Beihefte 48. ] (Wiesbaden: Franz Steiner Verlag, 1964-1965).

137. AD Tarn, C 1167, f 230.

138. Chabans, pp. 184-85.

139. Deliberations of the états de Languedoc held at Pézenas in 1620, AD Hérault, C 7059, $f^{\circ} 38-42$

140. For example, A. Lloyd Moote, Louis XIII, the Just (Berkeley: University of California Press, 1989), pp. 124-25.

141. Brian Sandberg, "The Infection of Heresy: Religious Conquest and Confessional Violence in Early Modern France,” in (Re)Constructing Cultures of Violence and Peace, ed. Richard Jackson (Amsterdam: Rodopi, 2004), pp. 17-30.

142. Lynn, The Bayonets of the Republic, pp. 21-40.

143. François de Bassompierre, Journal de ma vie: Mémoires du maréchal de Bassompierre (Paris: Société de l'Histoire de France, 1870-1877), vol. 2, pp. 321-23.

144. Luc Racaut, "The Polemical Use of the Albigensian Crusade During the French Wars of Religion,” French History 13 (1999), pp. 261-79; Richard L. Rubenstein, "Holocaust and Holy War," Annals of the American Academy of Political and Social Science 548 (November 1996), pp. 36-38; Mark Grimsley and Clifford J. Rogers, eds., Civilians in the Path of War (Lincoln: University of Nebraska Press, 2002), p. x.

145. Davis, "The Rites of Violence." On this point, see: Sandberg, "Rituels de violence religieuse pendant les derniers guerres de religion, 1598-1629,” (forthcoming).

146. La trompette divine et royalle, adresse avx fidelles seruiteurs \& subjects du roy (Paris: Claude Hulpeau, 1615).

147. For analysis of Calvinist acts of violence against Catholics, see: Tulchin, "The Michelade in Nîmes, 1567,” pp. 1-35.

148. Rose, pp. 783-808.

149. Hélène Duccini, Concini. Grandeur et misère du favori de Marie de Médicis (Paris: Albin Michel, 1991), pp. 322-36.

150. Orest Ranum, “The French Ritual of Tyrannicide in the Late Sixteenth Century,” Sixteenth Century Journal 11 (Spring 1980), pp. 63-82. 
151. Duccini, Concini, pp. 362-89.

152. Chabans, pp. 127-129.

153. Louis XIII to Antoine-Arnaud de Pardaillan, seigneur de Gondin, Aspremont, 17 April 1622, BNF, 1132, f 288-289.

154. “Di Parigi l'ultimo dell'anno 1627,” insert in Giovan Battista Gondi to [?], Paris, 31 December 1627, ASF, MdP 4640, f ${ }^{\circ}$ 746-751.

155. Giovan Battista Gondi to [?], Paris, 31 December 1627, ASF, MdP 4640, f 752-758.

156. Les commentaires du soldat du Vivarais (Valence: La Bouquinerie, 1991), pp. 157-158.

157. On the siege of Négrepelisse, see: Brian Sandberg, “'Only the Sack and the Noose for its Citizens': Atrocities against Civilians in the Wars of Religion in Early SeventeenthCentury France,” in Collateral Damage: Civilian Casualties, War and Empire, ed. Rick Halpern and Stephen Rockel, forthcoming.

158. Commentaires du soldat du Vivarais, pp. 15-17.

159. Commentaires du soldat du Vivarais, p. 77.

160. Commentaires du soldat du Vivarais, pp. 194-95.

161. Chabans, p. 656.

162. Chabans, p. 658.

163. Genesis 19.

164. “The Edict of Nantes with Its Secret Articles and Brevets,” p. 41.

165. Olivier Christin, La paix de religion; André Stegman, ed., Les édits des guerres de religion (Paris: Vrin, 1979).

166. Pierre Jeannin to Curzio da Picchena, Nancy, 14 October 1616, ASF, MdP 4759, f [957].

167. Traiano Guiscardi to Caterina di Ferdinando I de’ Medici duchessa di Mantova, Paris, 20 April 1618, ASF, MdP 6113, n.p.

168. Henri de Lorraine duc de Mayenne to Marie de Médicis, copy, BNF, Cinq Cens de Colbert $97, \mathrm{f}^{\circ} 24$.

169. Giustiniano Priandi to Caterina di Ferdinando I de’ Medici duchessa di Mantova, Paris, 14 June 1619, ASF, MdP 6113, n.p.

170. “Copie di lettere scritte al Residente Bartolini,” Brissac, 10 August 1620, ASF, MdP 4635, n.p.

171. Marie de Médicis to Maria Maddalena von Habsburg, Paris, 12 December 1620, ASF, MdP 4729A, f 428.

172. Claude Bullion sieur de Bonnelles to Henri de Rohan duc de Rohan, Valence, 1 August 1622, BNF, Mss. fr. 15583, f 94.

173. Christin, pp. 55-61.

174. Seong-Hak Kim, “'Dieu nous garde de la messe du chancelier’: The Religious Belief and Political Opinion of Michel De L’hopital,” Sixteenth Century Journal 24 (Autumn 1993), pp. 595-620.

175. Daubresse, pp. 71-120. 
182/ Renaissance and Reformation / Renaissance et Réforme

176. For a broad examination of the production and reception of the Edict of Nantes, see: Paul Mironneau and Isabelle Pébay-Clottes, eds., Paix des armes, paix des âmes.

177. On the possibilities of coexistence, see: Keith Luria, Sacred Boundaries: Religious Coexistence and Conflict in Early-Modern France (Washington, DC: Catholic University of America Press, 2005); Keith Luria, "Separated by Death? Burials, Cemeteries, and Confessional Boundaries in Seventeenth-Century France,” French Historical Studies 24 (Spring 2001), pp. 185-222; Hanlon, Confession and Community in Seventeenth-Century France.

178. Philippe Chareyre, “Trente ans après: de la paix à la grâce, l'édit de Nîmes, juillet 1629,” in Paix des armes, paix des âmes, pp. 343-70.

179. The dynamics and religious-political cultures of later French civil conflicts with a religious dimension — such as the dragonnades, the Camisards uprising, and the Vendéen civil war-were very different from those of the religious wars of 1562-1629.

180. Crouzet, vol. 1, pp. 75-81.

181. Crouzet's study, in part because it is based primarily on contemporary polemical literature, offers a fascinating but somewhat narrow perspective on God's place in religious conflict. Crouzet, vol. 2, pp. 574-628.

182. Recent research suggests that lay Catholics in the southern Netherlands remained essentially passive in the conflicts of the Dutch Revolt, but does not consider their participation in the operations of the Spanish Army of Flanders in those conflicts. Judith Pollman, "Countering the Reformation in France and the Netherlands: Clerical Leadership and Catholic Violence, 1560-1585,” Past and Present 190 (February 2006), pp. 83-120.

183. For descriptions of Henri II de Montmorency's execution and Toulousain reactions, see: BNF, Mss. fr. 18457, f 90-95; AD Haute-Garonne, B 525, B 1879, and Mss. 129.

184. Du Cros, pp. 267-68. 